\title{
Gas hydrates in the Ulleung Basin, East Sea of Korea
}

\author{
Byong-Jae Ryu ${ }^{1, *}$ and Michael Riedel ${ }^{2}$ \\ ${ }^{1}$ Korea Institute of Geoscience and Mineral Resources, Daejeon, Korea \\ ${ }^{2}$ GEOMAR Helmholtz-Centre for Ocean Research, Kiel, Germany
}

\section{Article history: \\ Received 6 February 2017 \\ Revised 14 September 2017 \\ Accepted 21 October 2017 \\ Keywords: \\ Gas hydrate, Ulleung Basin, Bot- tom simulating reflector, Chimney structure \\ Citation:}

Ryu, B.-J. and M. Riedel, 2017: Gas hydrates in the Ulleung Basin, East Sea of Korea. Terr. Atmos. Ocean. Sci., 28, 943-963, doi: 10.3319/ TAO.2017.10.21.01

\begin{abstract}
To develop gas hydrates as a potential energy source, geophysical surveys and geological studies of gas hydrates in the Ulleung Basin, East Sea off the east coast of Korea have been carried out since 1997. Bottom-simulating reflector (BSR), initially used indicator for the potential presence of gas hydrates was first identified on seismic data acquired in 1998. Based on the early results of preliminary R\&D project, $12367 \mathrm{~km}$ of 2D multichannel reflection seismic lines, 38 piston cores, and multi-beam echo-sounder data were collected from 2000 to 2004. The cores showed high amounts of total organic carbon and high residual hydrocarbon gas levels. Gas composition and isotope ratios define it as of primarily biogenic origin. In addition to the BSRs that are widespread across the basin, numerous chimney structures were found in seismic data. These features indicate a high potential of the Ulleung Basin to host significant amounts of gas hydrate. Dedicated geophysical surveys, geological and experimental studies were carried out culminating in two deep drilling expeditions, completed in 2007 and 2010. Sediment coring (including pressure coring), and a comprehensive well log program complements the regional studies and were used for a resource assessment. Two targets for a future test-production are currently proposed: pore-filling gas hydrate in sand-dominated sediments and massive occurrences of gas hydrate within chimney-like structures. An environmental impact study has been launched to evaluate any potential risks to production.
\end{abstract}

\section{INTRODUCTION}

Gas hydrate is a solid substance composed of water and natural gas, mainly methane (e.g., Makogon 1997; Sloan 1998; Kvenvolden and Lorenson 2001), but it is stable only under specific conditions, of low temperature and high pressure. Kvenvolden (1993) estimated the worldwide amount of methane in gas hydrates is to be equivalent to at least $10^{4}$ gigatons of organic carbon. Moreover, gas hydrate is regarded as an environmentally energy source since the amount of $\mathrm{CO}_{2}$ release during methane combustion in gas hydrate is $70 \%$, less than in currently used petroleum (Matsumoto et al. 1994). Thus, gas hydrate is regarded as a future energy resource (e.g., Boswell and Collett 2011) since it has represented a major reservoir of methane in the Earth. Gas hydrate is easily dissociated to gas by small changes in temperature and/or pressure conditions. Methane escape into the atmosphere from gas hydrate reservoirs thus may

\footnotetext{
* Corresponding author

E-mail:bjryu@kigam.re.kr
}

effect global and enhance global warming (see e.g., discussion on the Clathrate gun hypothesis by Kennett et al. 2003 and other discussions such as MacDonald 1990; Haq 2000; Archer 2007). The dissociated methane and liberated fresh water may cause submarine landslides and subsidence (e.g., McIver 1982; Paull et al. 2000a; Maslin et al. 2010). Therefore, studies on gas hydrate have attracted attention worldwide.

Here, we summarize evidences for the presence of gas hydrate in the Ulleung Basin, East Sea of Korea (Fig. 1) that reflect both regional and focused modes of gas hydrate accumulations.

A bottom-simulating reflector (BSR) is commonly used as a geophysical indicator of the presence of marine gas hydrates (e.g., described in the review by Spence et al. 2010), and is often used to provide an initial assessment of the potential gas hydrate distribution. BSRs occur at the interface between overlying gas hydrate-bearing sediments with higher velocity and underlying gas-bearing sediments 
with lower velocity. BSRs are generally nearly parallel to the sea floor following an isotherm. BSR sub-bottom depths increase with increasing water depth, following the pressure-temperature phase stability of gas hydrate. They are often characterized by large reflection coefficients and reflection polarity opposite to that of the seafloor reflection as shown by earlier studies (e.g., Shipley et al. 1979; Hyndman and Spence 1992; Paull et al. 1997).

Vertical to sub-vertical seismic blanking zones of reduced reflectivity are one of the more recently recognized indicators of gas hydrate and are observed worldwide in association with upward focused fluid flow (e.g., Gorman et al. 2002; Riedel et al. 2002; Ryu et al. 2009; Petersen et al. 2010). Only a few of these structures have been studied in detail, but blanking zones are often associated with cold fluid and gas vents characterized by extensive seafloor carbon- ate formations and cold-vent chemosynthetic communities. A number of hydrate samples were retrieved from blanking zones by piston coring and deep-drilling in the Ulleung Basin (e.g., Park et al. 2008; Ryu et al. 2013).

However, where gas hydrate is not recovered (but dissociated during recovery), there are a number of indicators for the presence of in-situ gas hydrate. Features such as bedding-parallel cracks and sediment louse-like or soupy textures were well observed in cores of ODP Leg 146 (Westbrook et al. 1994; Kastner et al. 1995), and are considered indicators for dissociation of in-situ gas hydrates. Cracks formed by gas expansion were also seen in Cascadia cores of ODP Leg 204 (e.g., Riedel et al. 2006a), and both cracks and soupy layers were observed in cores from the Ulleung Basin, (Ryu et al. 2004, 2009). Other indicators of in-situ gas hydrate that has dissociated upon recovery are cold core

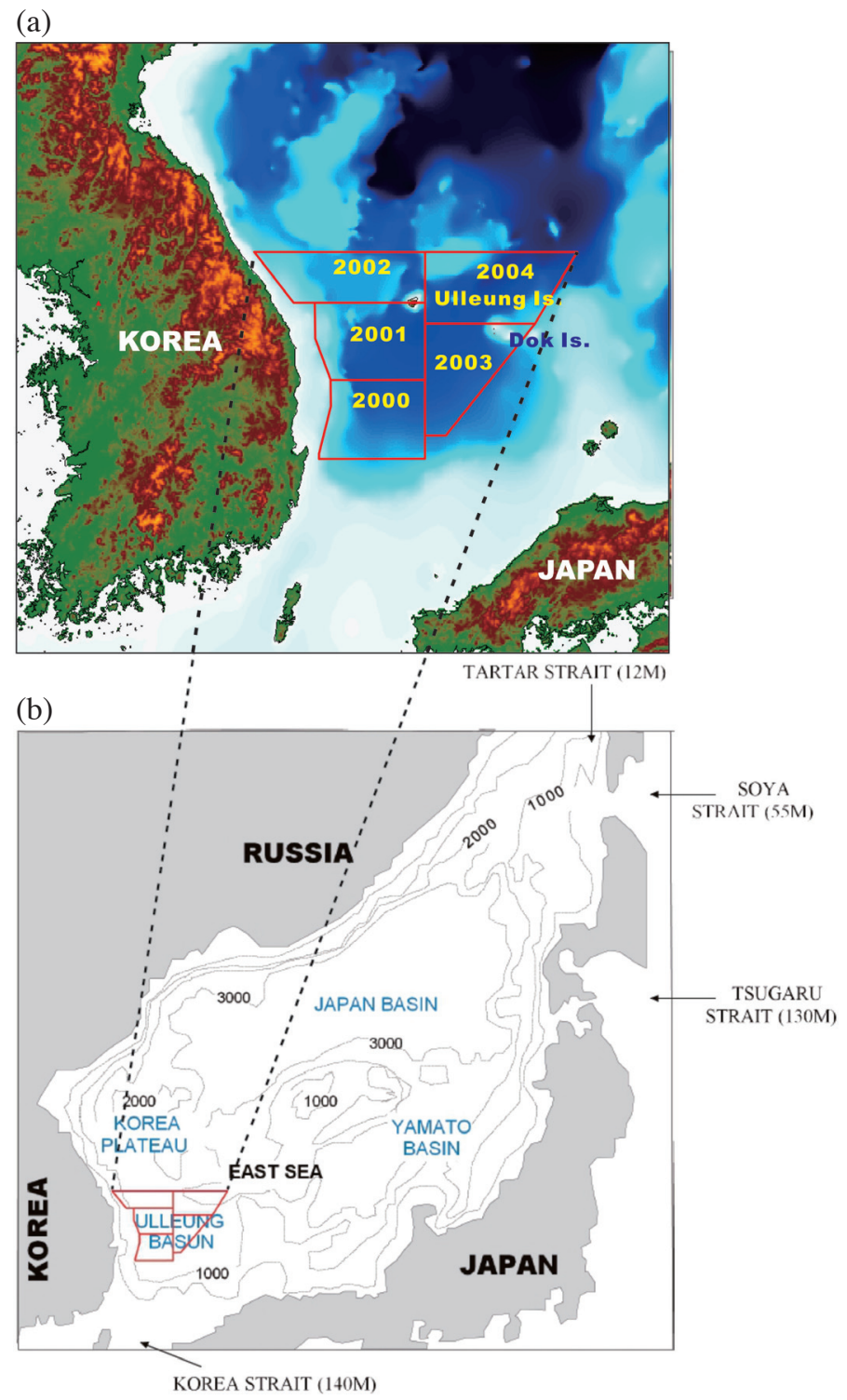

Fig. 1. Physiographic map of the East Sea and the surrounding region. Box indicates study area expanded in (b). 
temperatures immediately upon recovery (Long et al. 2003; Tréhu et al. 2004; Riedel et al. 2006b; Su et al. 2006; Ryu et al. 2012, 2013), and reduced pore fluid chlorinities relative to a given regional background trend (Kastner et al. 1995; Paull et al. 2000b; Tomaru et al. 2006; Ryu et al. 2012, 2013).

Initial geophysical exploration and studies of the U1leung Basin were performed mostly to explore for conventional oil along the southern continental shelf since the late 1960s. Since the early 1990s, research surveys in the deepwater area of the East Sea were focused on the tectonic history, sediment stratigraphy and paleoenvironment of the sea and were carried out by the Korea Institute of Geoscience and Mineral Resources (KIGAM) and the Korea Ocean Research and Development Institute (KORDI; currently Korea Institute of Ocean Science and Technology: KIOST). Evidence for the presence of gas hydrate in the basin was first reported by Gardner et al. (1998) using side-scan sonar images, sediment samples, and $3.5 \mathrm{kHz}$ sub-bottom profiling data.

The occurrence of BSRs off Korea was first recognized by Jang et al. (1999) using multichannel seismic lines acquired using the R/V TAMHAE-II in the southwestern part of the Ulleung Basin. An additional, preliminary study of geophysical indicators of gas hydrates in the Ulleung Basin using multichannel seismic data was reported by Lee et al. (2005). A regional geological and thermal interpretation was provided by Horozal et al. (2009) and Ryu et al. (2009).

As a part of the Korean National Gas Hydrate Program, the first Ulleung Basin Gas Hydrate Drilling Expedition (UBGH1) was conducted in 2007 to delineate the gas hydrate potential in the basin (Park et al. 2008). Coring and downhole well logging were performed using the M/V Rem Etive. A total of five LWD/MWD boreholes, three core and in-situ testing boreholes in the vicinity of the corresponding LWD/MWD boreholes, and one WL/VSP survey were completed (Park et al. 2008). Although UBGH1 provided valuable information on the presence of gas hydrate in potentially significant amounts suitable for exploitation, gas hydrate-bearing sediments were confirmed at only a few sites. Sparse scientific information on the nature of gas hydrate-bearing structures limited the ability to assess the regional gas hydrate resource potential. Thus, a second drilling expedition (UBGH2) was conducted in 2010 (Ryu et al. 2013) using the D/V Fugro Synergy. The objectives of UBGH2 were (1) to confirm the occurrence of gas hydratebearing sediments in the basin (at 13 sites), and (2) to obtain a suite of scientific information on the distribution of gas hydrate-bearing accumulations as needed to conduct a more rigorous gas hydrate resource assessment. Various types of gas hydrates were recovered during the $2^{\text {nd }}$ drilling expedition (Ryu et al. 2012, 2013) and results of the drilling expeditions are summarized below. Additionally, we report on results from piston cores analyses taken across the Basin in the years of 2000 - 2004 and new seismic data interpretation, augmenting the regional coverage of seismic data across the basin. These data complement the vast amount of already existing geo-scientific knowledge of the gas hydrate occurrences in the Ulleung Basin and provide a complementary view of the existing findings.

\section{REGIONAL SETTING OF THE ULLEUNG BASIN}

The Ulleung Basin is located in the southwestern East Sea off the east coast of Korea (Fig. 1). The East Sea is a semi-closed marginal sea between the Eurasian continent in the West and the Japan Arc in the East. It is connected to the open ocean through shallow straits (12 - $140 \mathrm{~m}$ deep, Moriyasu 1972). The East Sea is divided onto three deep oceanic sedimentary basins: Ulleung, Yamato, and Japan Basin. These basins are individually separated by submarine topographic highs such as the Korea Plateau, Yamato Ridge, and the Oki Bank. The western continental shelf of the basin is narrow $(40-50 \mathrm{~km})$ and flanked by steep slopes $\left(2-4^{\circ}\right)$, whereas the shelves on the south and east are broad and flanked by rather gentle slopes $\left(<2^{\circ}\right)$. The basin floor gradually deepens to the north and northeast from $1000-2300 \mathrm{~m}$. Several seamounts formed by volcanic activity in the northeastern part of the basinclose to Dok Island. The basin is connected northward to the Japan Basin through the Korea Gap previously known as Ulleung Interplain Gap, a long narrow interplain gap (Fig. 1) between Ulleung and Dok Islands.

During the Late Oligocene to Early Miocene period, the Ulleung Basin was formed through crustal extension associated with a southward drift of the Japan Arc away from the Asian mainland (Chough and Barg 1987; Tamaki et al. 1992; Jolivet et al. 1995). At the end of the Middle Miocene (approximately at $12 \mathrm{Ma}$ ), the general tectonic regime within the basin changed from extensional to compressional (Yoon and Chough 1995; Chough et al. 2000). This led to the development of thrust faults and folds in the southern and western margin of the basin. Additionally, the sedimentary successions were exposed to compression associated with consolidation that may have been a driving force for the upward flow of gas-rich fluids and subsequent gas hydrate formation (similar to processes postulated for an accretionary prism by Hyndman and Davis 1992 or Hyndman et al. 1993). Since the end of the Late Miocene, the basin has progressively subsided until the present setting has been reached (Park et al. 2002).

The sediment succession in the Ulleung Basin has been divided into four seismic sequence units by Chough et al. (2000). The lowermost unit is of Late Oligocene Early Miocene age and consists of volcanic flows and sills interbedded with sedimentary layers. This is overlain by a Middle Miocene unit consisting mostly of marine shales. This second unit is relatively uniform in thickness across the central basin. However, to the northeast, it gradually transitions into a unit that is characterized by massive sandstone/ shale, volcaniclastic and turbidite sequences. This third unit 
of Late Miocene to Early Pliocene age and consists again mostly of marine shale interbedded with thin sandstone and siltstone beds. Wiyjin this third unit, variation in grain size and associated permeability contrasts may provide significant controls on gas hydrate formation (either in form of coarse-grained host-sediments and/or fluid pathways). In the south-western region of the basin, this unit is in contrast characterized by occurrence of abundant slide or slump deposits. The uppermost unit of Late Pliocene - Quaternary age is dominated by turbidite and hemi-pelagic deposits embedded within the otherwise dominant shale-sequences. The uppermost (and youngest) unit is of Late Pliocene-Quaternary age. It is dominated by hemi-pelagic deposits interbedded with turbidites.

Based on this general geological setting and distribution of sediments across the Ulleung Basin, a focus of the $2^{\text {nd }}$ drilling expedition UBGH2 was to identify gas hydratebearing sand layers that could be economically developed (Boswell 2009). The regional sediment delivery system for sand was investigated and geologic models of sand occurrence were defined using a petroleum system approach to gas hydrate exploration (as shown by Collett et al. 2009). This also guided the site selection process for UBGH2.

Regional geothermal gradients were defined in the Ulleung Basin from seismic data using the BSR as an isotherm (Ryu et al. 2009) and near-surface heat-probe deployments (Huh et al. 2005). In order to further assess the thickness of the gas hydrate stability zone (GHSZ) in the basin, temperature measurements were made during UBGH2. In-situ formation temperatures measured using the WISON EP system during the UBGH2 revealed a high geothermal gradient, ranging from $96-115^{\circ} \mathrm{C} \mathrm{km}^{-1}$. The generally high geothermal gradients result in a shallow GHSZ, despite the large water depths exceeding $2000 \mathrm{~m}$.

\section{SUMMARY OF DRILLING EXPEDITIONS}

The two drilling expeditions in 2007 and 2010 followed a similar strategy. Prior to drilling, a careful site selection process was conducted including discussions with an International Scientific Advisory Committee (ISAC) in which scientists from U.S. Department of Energy, US Geological Survey, Geological Survey of Canada, Monterey Bay Aquarium Research Institute (MBARI), Birmingham University, Pukyong National University, Korea National Oil Corporation, and KORDI participated. The primary criteria used by the ISAC were (1) establishment of the extent of the gas hydrate stability zone (GHSZ), (2) evidence for gas sourcing and migration into the GHSZ, (3) evidence of gas hydrate presence within the GHSZ and, (4) evidence for the occurrence of a sand sedimentary facies within the GHSZ, suitable for potential production. A number of high priority sites were selected for drilling. Post-drilling verification of the main gas hydrate indicators chosen for drill- site selection was performed by Kang et al. (2015).

At each of these high priority sites (Fig. 2), first logging-while-drilling (LWD) was performed (5 sites for UBGH1 and 13 sites for UBGH2) to obtain first impressions on the possible occurrence of gas hydrates. The LWD data acquisition was performed together with measurementwhile-drilling (MWD) tools for continuous safety monitoring, following protocols develop during previous gas hydrate expeditions, such as IODP Expedition 311 (Riedel et al. 2006b) or the India National Gas Hydrate Program Expedition 01 (Collett et al. 2015). These data were used on board to select the best sites for coring and to develop a sampling and downhole-tools deployment program. Overall, the LWD data show various characteristics indicating presence of gas hydrate-bearing sediments (Kim et al. 2011). A series of sites within seismic chimney are characterized by anomalous log data of high resistivity and velocity values, compared to the surrounding (non-hydrate-bearing) marine sediments. Moreover, log values of low density (less than $1.1 \mathrm{~g} \mathrm{~cm}^{-3}$ ) and low gamma-ray values much below the average values indicate the presence of massive gas hydrates. Gas hydrates at the seismic chimney sites occurred within steeply inclined fractures in overall mud dominated sediments. These gas hydrate-filled fractures were also identified on X-ray images of recovered pressure cores (Park et al. 2009). However, such preferred orientation of fractures does create anisotropic effects for bore-hole measurements as shown by Lee and Collett (2013a, b).

Gas hydrate saturations were estimated from the various LWD and wire-line log electrical resistivity and P-wave velocity data from both drilling expeditions (e.g., Kim et al . 2008a, b, 2013a, b; Riedel et al. 2012, 2013a, b; Lee and Collett 2013b). The various approaches and results do show similar overall concentration estimates for those sites outside of seismic chimney structures (Ryu et al. 2013), but considerable difference were found for sites within seismic chimneys (Kim et al. 2013a). A different approach was taken by Tak et al. (2013) who estimated gas hydrate saturation at two Sites (UBGH2-6 and UBGH2-10) using wireline and vertical seismic profile (VSP) data. The VSP data allow the calculation of detailed interval velocities, but also yield highresolution corridor-stack reflection images that can be compared to the 2D regional multichannel seismic data. Their analysis shows concentrations ranging from $30-90 \%$ of the pore space at Site UBGH2-6, and 35 - 57\% at Site UBGH210 in the corresponding gas hydrate-bearing intervals.

Gas hydrate-bearing sediments within the recovered conventional-wire cores were identified visually when possible, but indirectly by cold infrared (IR) anomalies before core sectioning, and by low interstitial water salinities and chloride concentrations after pore-water extraction. Expansion cracks in the recovered conventional cores were also observed, which can indicate the presence of gas and/or gas hydrate in the core (e.g., Kvenvolden and Lorenson 2001; 


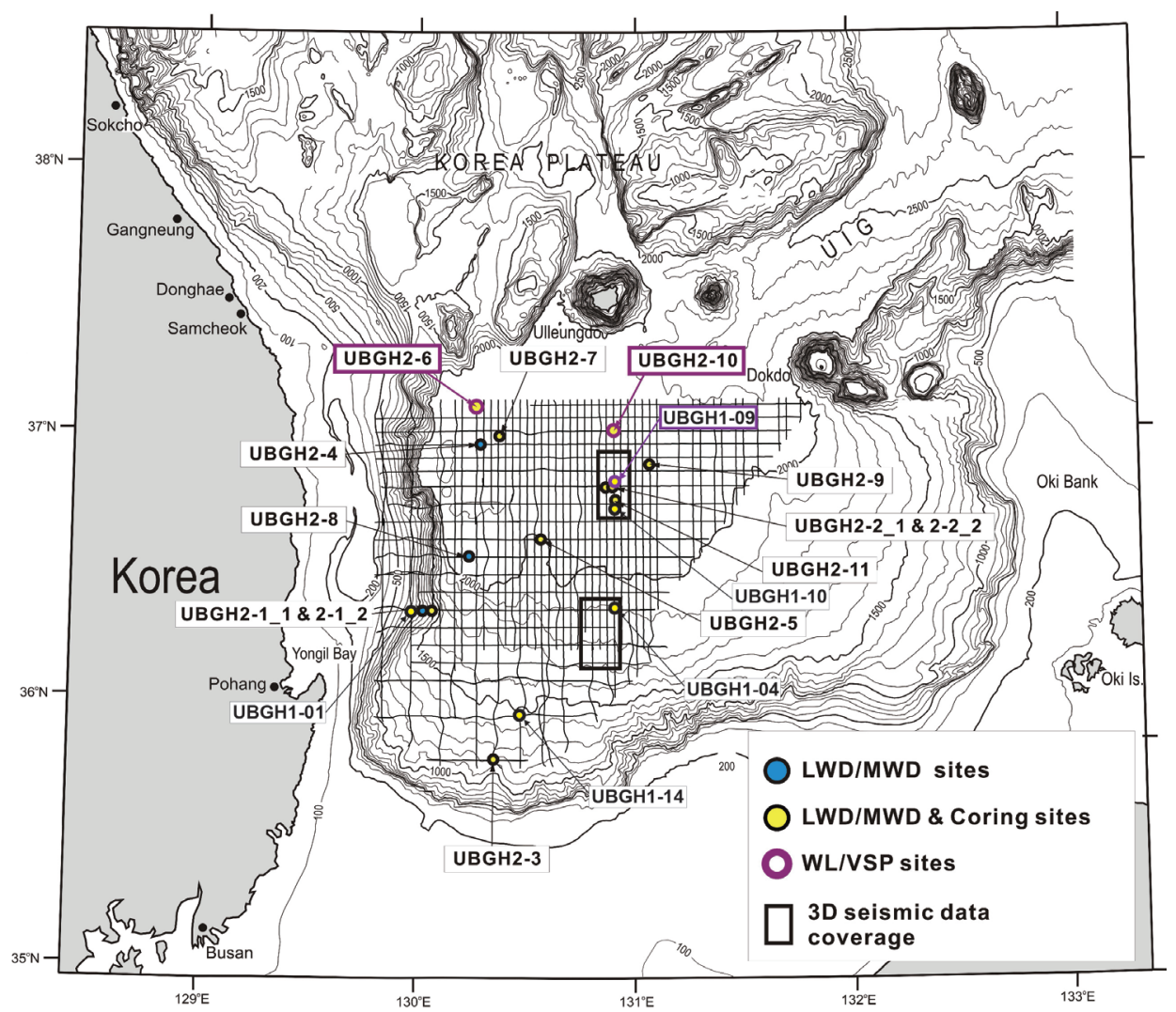

Fig. 2. UBGH site map depicting the location of drill sites, bathymetry, 2-D seismic lines collected in 2005, and 3-D survey areas (modified from Ryu et al. 2012).

Riedel et al. 2006b). Bahk et al. (2013a) defined the types of gas hydrates as "pore-filling" occurring sand layers, and "fracture-filling" in veins and nodules or "disseminated" type in mud without apparent lithologic controls. In addition, "porefilling" hydrates in diatomaceous mud were also found where gas hydrate occupies sediment layers dominated by diatom frustules. The saturation of gas hydrate in the sandy sediment "pore-filling" type was shown to be directly related to sand content with the sedimentary section, with a nearly linear increase in gas hydrate saturation with increasing sand content. In the case of "pore-filling" type hydrates within diatomaceous mud, the fossil diatoms offer the pore-space for the formation and growth of gas hydrates, which limits the use of gamma ray and density logs in discriminating these types of hydrate-bearing sediments (Bahk et al. 2013b).

Significant gas hydrate occurrences within the logged and cored chimney structures from near the seafloor to the base of the GHSZ suggest that the chimney structure may represent a pathway for enhanced fluid and gas migration into and possibly through the GHSZ. Results from UBGH2 core studies along with the analysis of similar samples from UBGH1 have contributed greatly to our understanding of lithologic controls on marine gas hydrate occurrences. Bahk et al. (2013a) further examine the occurrence of gas hydratebearing sands at the Sites UBGH2-2_2 and UBGH2-6.
Gas and isotopic analyses indicate that the methane gas within the gas hydrate samples (and recovered from headspace or sediment void samples) in the Ulleung Basin is biogenic origin (Choi et al. 2013). Kim et al. (2013d) reported pore-water freshening caused by clay mineral dehydration, and an apparent relatively high rate of methane consumption by anaerobic oxidation of methane (AOM) in the basin, supported by a relatively high methane flux rate into the GHSZ.

\section{MATERIALS AND METHODS}

\subsection{Core Sampling and Analyses}

A total number of 38 piston cores with $5-8 \mathrm{~m}$ length were taken across the Ulleung Basin prior to the first drilling expedition in 2007 and here reported for the first time in a complete study (00GHP: 16 cores, 01GHP: 7 cores, 02GHP: 5 cores, 03GHP: 5 cores, $04 \mathrm{GHP}: 5$ cores; Table 1 ). The cores were kept in the cold sample storage of the R/V TAMHAE-II at $4^{\circ} \mathrm{C}$ under constant humidity conditions immediately after their recovery and transported to the core repository at the KIGAM using a refrigerated car.

Cores were analyzed for (1) sedimentary textures and facies, (2) total organic carbon (TOC), carbon (C), hydrogen $(\mathrm{H})$, nitrogen $(\mathrm{N})$, and sulfur $(\mathrm{S})$, (3) the origin, composition and concentration of residual hydrocarbon gases 
in wet sediments, and (4) the depth of the sulfate-methane transition zone (SMTZ). In the laboratory at KIGAM, the cores were split and one half preserved as an archive and the other half processed as a working core. X-ray radiographs of $1 \mathrm{~cm}$ thick slabs were taken to analyze the sedimentary textures and facies.

Radiocarbon dating using foraminifera $\left({ }^{14} \mathrm{C}\right)$ was performed by accelerator mass spectrometry (AMS) for samples taken from two cores of the 2001 study region.

A total of 2369 samples were selected at $5-10 \mathrm{~cm}$ intervals from 25 cores collected from 2000 - 2004 (Table 1). The samples were freeze-dried and ground to powders for further analyses. TOC contents of the sediments were measured using the Rock-Eval pyrolysis technique that has often been used for the evaluation of the hydrocarbon source-rock potential of sedimentary rocks as shown by earlier studies (Tissot and Welte 1984; Peters 1986). N and S were also measured to determine TOC/N and TOC/S ratios, which are commonly used to determine the origin and depositional environments of the organic matter in sediments (Stein 1991). Elemental, and Rock-Eval pyrolysis analyses were performed using a LECO CHN-600 and a LECO SC-132, and a VINCI Rock-Eval-6 at KIGAM.

Concentrations of residual hydrocarbon gases in the cored sediments were analyzed using the headspace technique. For the cores collected prior to publication of ODP Technical Note 30 by Pimmel and Claypool (2001), samples were taken onboard after core recovery and immediately placed with seawater into sealed cans as was the common procedure on hydrocarbon exploration drill ships. For the cores retrieved in 2002 (01GHP-05 through 01GHP-07), two $5-\mathrm{cm}^{3}$ samples were taken from each core onboard after recovery and immediately placed into a $20-\mathrm{cm}^{3}$ vial as described by Pimmel and Claypool (2001). In 2002, the samples were analyzed by both using a sealed can and a vial for comparison. There was no significant difference in the residual hydrocarbon gas results for the different sampling techniques. However, a total of 65 samples selected from 10 in 2003 and 2004 analyzed using a vial to follow the newly established ODP protocol.

Gas extracted from the head-space samples was in- jected with a glass syringe into a Hewlett Packard HP 5890 II gas chromatograph (GC) at the KIGAM laboratory. The concentration of headspace gases was calculated using sample weight, total weight, sample volume, space volume, sediment volume, and pore water volume. Carbon isotopic compositions $\left(\delta^{13} \mathrm{C}\right)$ of the residual hydrocarbon gases were determined using isotope ratio mass spectrometry (IRMS) at the Korea Research Institute of Standard and Science (KRISS) using the same samples used for headspace gas analysis. The IRMS consists of a Hewlett Packard HP 6890 GC and a Finnigan MAT GC Combustion III, with analytical reproducibility of $\pm 0.4 \%$.

The concentrations of sulfate $\left(\mathrm{SO}_{4}{ }^{2-}\right)$ were analyzed to define the sulfate-methane transition zone (SMTZ) depths, which are used to estimate the upward methane fluxes (e.g., Borowski et al. 1996). Sulfate was analyzed using pore water extracted from two piston cores of the 00GHP study area as described by Gieskes et al. (1991) and immediately placed into the glass vial as described by Pimmel and Claypool (2001). These two cores were duplicated of cores 00GHP07 and 00GHP-14. The pore water was extracted from core samples by centrifuging for $30 \mathrm{~min}$ at $10000 \mathrm{rpm}$. The water was collected with a syringe and filtered using $0.45-\mu \mathrm{m}$ membrane filters. Sulfate was analyzed using Dionex ion chromatography (DX-500 IC) with an AS-40 autosampler at the Seoul National University in Korea. The SMTZ of cores of the 01GHP study area were determined using the sulfate concentrations reported by Park et al. (2005).

Methods on analyzing deep drill cores taken during the drilling expedition UBGH1 and UBGH2 are described in Fugro (2007) and Ryu et al. (2012), respectively, and are not repeated here.

\subsection{Geophysical Data Acquisition and Processing}

To determine the potential areas of gas hydrate accumulation in the jurisdictional sea of Korea, a total 12366 line- $\mathrm{km}$ 2D multichannel digital seismic data were acquired by using Trilogy System of Geco-Prakla and Bolt Air-gun System. Seismic data were processed to define the BSRs and seismic blank zones using Gecoseis, Geobit, Globe

Table 1. Summary of piston cores and core analysis.

\begin{tabular}{c|cccc}
\hline Year & Survey area $\left(\mathbf{k m}^{2}\right)$ & Number of retrieved piston cores (water depth, mbsl) & Number of analyzed samples & Number of analyzed cores \\
\hline 2000 & 8325 & $16(846-1868)$ & 422 & 4 \\
2001 & 8330 & $4(790-2147)$ & 363 & 4 \\
2002 & 8604 & $8(3$ in 2001 study area) $(1233-2174)$ & 436 & 7 \\
2003 & 8735 & $5(1197-2179)$ & 497 & 5 \\
2004 & 12300 & $5(2283-2450)$ & 651 & 5 \\
\hline Total & 46294 & $38(790-2450)$ & 2369 & 25 \\
\hline
\end{tabular}

Note: mbsl: meter below sealevel. 
Claritas, and ProMax. In addition, a total of 10491 line-km single channel seismic data were also acquired by using Sonar Enhancement System of GeoAcoustics and MESH200P hydrophone array of Benthos. The single channel seismic data were also processed by using SE881 Sonar Enhancement Work Station and version 3.5 software of GeoAcoustics. The systematic processing of the multichannel seismic data included geometry definition and CMP sorting, bandpass filter, deconvolution, normal move-out correction (in iteration with semblance velocity analysis), stack, and timemigration. Single-channel data were processed only by including bandpass filters, deconvolution and time-migration using extrapolated (and assumed) velocity functions from the MCS data. Additionally, three 3D seismic data volumes totaling $>900 \mathrm{~km}^{2}$ (Table 2) were acquired for detailed analyses over key research areas (around Site UBGH14 for detailed MTD analyses, across the seismic chimney structures and Sites UBGH1-9, UBGH1-10, UBGH2-2_1, UBGH2-2_2, and UBGH2-10).

Seismic data were mainly processed to define the regional distribution of BSRs and seismic blank zones (e.g., Ryu et al. 2004, 2009; Lee et al. 2005; Yoo et al. 2008, 2013; Horozal et al. 2009) as primary indicators for gas hydrates. The vertical extent of the GHSZ across the basin was defined either by using the BSRs or thermal modeling. The thermal modeling is based on seafloor temperatures measured with bathythermographs and sub-seafloor geothermal gradients measured with surface heat-probes (Huh et al. 2005). The gas hydrate phase equilibrium conditions were further defined based on results of head space gas analyses from cores recovered across the basin, results of ODP Leg 127, and assumed (or extrapolated) in situ pore-water salinities.

Reflection coefficients of the seafloor were estimated by Ryu et al. (2009) using the seafloor multiple method (Warner 1990) and the corresponding reflection coefficients for the BSR were then calculated using the reflection amplitude of the BSR and a conversion factor estimated from the seafloor reflection coefficients. These data were used to guide the search for potentially high gas hydrate or free gas accumulations across the basin as well as to establish regional seismic velocity-depth functions that were utilized to define regional gas hydrate concentrations (Ryu et al. 2009). Additional specialized seismic processing was performed on a subset of the available data with the aim to define possible concentrations of gas hydrate and free gas, with a focus on the reflection characteristics of BSRs. Special processing tools applied include amplitude-versus offset (AVO) analyses, full-waveform inversion using the method shown by Yuan et al (1999), and band-limited impedance inversion (Grevemeyer et al. 2000) and were reported by Ryu et al. (2009).

\subsection{Seismic- and Echofacies Classification}

Shallow sub-seafloor echofacies were defined across the Ulleung Basin and South Korea Plateau from 2D multichannel seismic data collected from 2000 - 2004 (Ryu et al. 2004). The facies were classified using the reflection characteristics as means to differentiate individual classes and then linked to sedimentological and sediment character using all available core and drill data. Three main facies were defined: Echofacies I represents continuous and well stratified reflections (Fig. 3a). Echofacies II is characterized by chaotic or transparent reflections, and echofacies III is defined by occurrence of unconformities and channels (Figs. $3 \mathrm{~b}$ and c).

\section{RESULTS AND DISCUSSION}

\subsection{Geological and Geochemical Indicators for Gas Hydrate in Cores}

Gas hydrates contained in cored sediments is often largely dissociated due to pressure decrease and temperature increase upon recovery on deck. When gas hydrate dissociates, it forms gas and (nearly) pure water that induces cracks and other disturbances in the sediment textures and freshening of the pore waters. Results on these features from the drilling expeditions are reported in Fugro (2007); Ryu et al.

Table 2. Acquisition parameters of 2D multi-channel seismic data analyzed for this study.

\begin{tabular}{|c|c|c|c|c|c|c|c|c|c|}
\hline Year & $\begin{array}{c}\text { Amount of acquired } \\
\text { seismic lines (km) }\end{array}$ & $\begin{array}{c}\text { No. of se- } \\
\text { quences }\end{array}$ & $\begin{array}{l}\text { Streamer } \\
\text { length }(m)\end{array}$ & $\begin{array}{c}\text { No. of } \\
\text { channel }\end{array}$ & $\begin{array}{c}\text { Source volume } \\
\left(\text { in }^{3}\right)\end{array}$ & $\begin{array}{c}\text { Source pres- } \\
\text { sure (psi) }\end{array}$ & $\begin{array}{l}\text { Record length } \\
\text { (sec) }\end{array}$ & $\begin{array}{c}\text { Sample } \\
\text { rate }(\mathrm{ms})\end{array}$ & Group interval (m) \\
\hline 2000 & 2511.1885 & 29 & 600 & 96 & $\begin{array}{c}245 \text { for seq. } 19 \\
454 \text { for seq. } 5 \\
1035 \text { for seq. } 28 \\
299 \text { for other seqs. }\end{array}$ & 2000 & 4 & 1 & 6.25 \\
\hline 2001 & 2277.2325 & 30 & 1000 & 80 & $\begin{array}{c}925 \text { for seqs. } \\
1-25 \\
\text { for seqs. } 26-30\end{array}$ & 2000 & $\begin{array}{c}4 \text { for seqs. } 1-25 \\
8 \text { for seqs. } 26 \\
-30 \\
\end{array}$ & 1 & $\begin{array}{l}6.25 \text { for seqs. } 1-25 \\
12.5 \text { for seqs. } 6-30\end{array}$ \\
\hline 2002 & 2650.0250 & 31 & 1000 & 80 & 1254 & 2000 & 6 & 1 & 12.5 \\
\hline 2003 & 2404.4000 & 32 & 1000 & 80 & 1035 & 2000 & 6 & 1 & 12.5 \\
\hline 2004 & 2529.5500 & 24 & 1000 & 80 & 1035 & 2000 & 6 & 1 & 12.5 \\
\hline
\end{tabular}

Note: in $^{3}$ : cubic inches. 


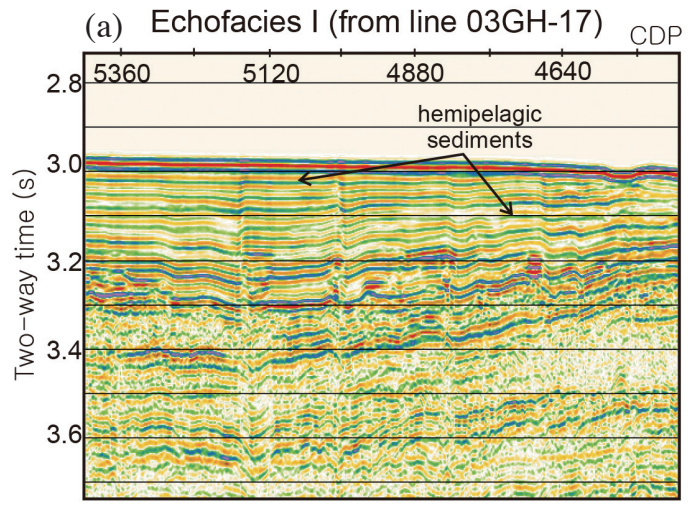

(c) Echofacies III (from line 04GH-07)

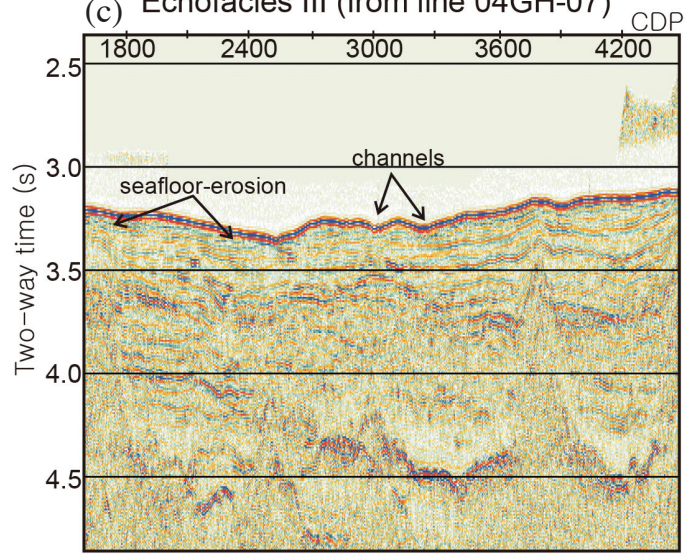

(b) Echofacies II (from line 03GH-21)

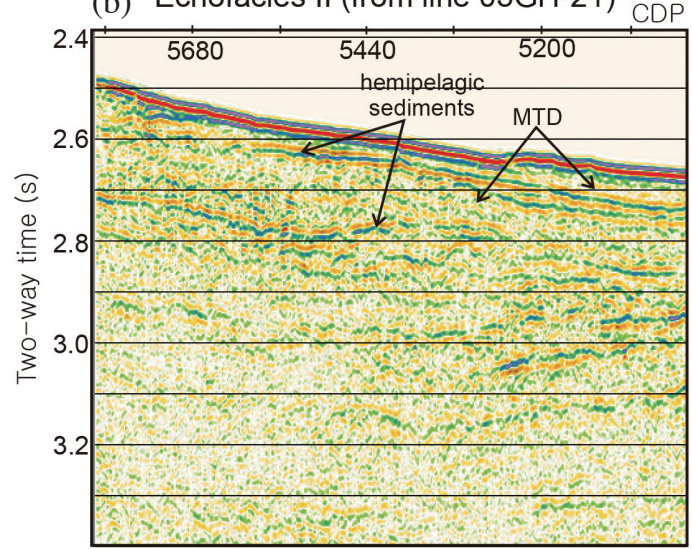

Fig. 3. Examples of three main echo facies defined from multichannel seismic data in the Ulleung Basin.

(2012, 2013); Bahk et al. (2013a); and Kim et al. (2013d).

\subsubsection{Core Sedimentary Textures}

Cracks generally developed parallel to the bedding and were observed in the deeper intervals of cores 00GHP01, 00GHP-07, 00GHP-11, 01GHP-03,03GHP-01, and 01GHP-01 (Fig. 4). The cracks are interpreted to have formed as a result of gas expansion upon recovery. Fluidrich intervals with characteristic mousse-like textures from dissociating gas hydrates were also observed in these piston cores (Fig. 4).

\subsubsection{TOC Contents}

Total Organic Carbon (TOC) is an important indicator of the potential for substantial hydrocarbon gas generation. In all piston cores, contents of TOC content ranged from $0.55-2.39 \%$ with an average value of $1.7 \%$ (Fig. 5). A total of 2113 samples among 2369 samples (90\% of analyzed samples) show the TOC values above $0.5 \%$. These results are sufficient for the formation of gas hydrate. Two intervals of core 00GHP-14 containing very low contents of TOC are mainly composed of coarser-grained sediments (silt- and sand-sized). The organic matter in the sediments are originated from the marine algae, and deposited in anoxic/euxinic environments

\subsubsection{Sedimentation Rates}

Sedimentation rates were defined for cores 01GHP04 and 01GHP-06 using the radiocarbon ages defined from AMS. The sedimentation rate showed a variation from 71 $253 \mathrm{~m} / 10^{6} \mathrm{yr}$ (mean: $168 \mathrm{~m} / 10^{6} \mathrm{yr}$ ), and from $62-640 \mathrm{~m} / 10^{6} \mathrm{yr}$ (mean: $190 \mathrm{~m} / 10^{6} \mathrm{yr}$ ), respectively (Fig. 6). Considering that sedimentation rates should be higher than $30 \mathrm{~m} / 10^{6} \mathrm{yr}$ to form gas hydrate (Sloan 1998), we believe that the above results are sufficient in general for the formation of gas hydrate.

\subsubsection{Residual Hydrocarbon Gas Concentrations}

Residual hydrocarbon gas concentration is an important indicator of the potential for formation of gas hydrate within the GHSZ. Sediments below the SMTZ as defined from some piston cores and UBGH2 drill cores showed generally higher concentration than $10 \mathrm{ml} / \mathrm{l}$ wet sediment (Fig. 7). These results indicate that the sediments have sufficient condition in order for gas hydrate to form following 


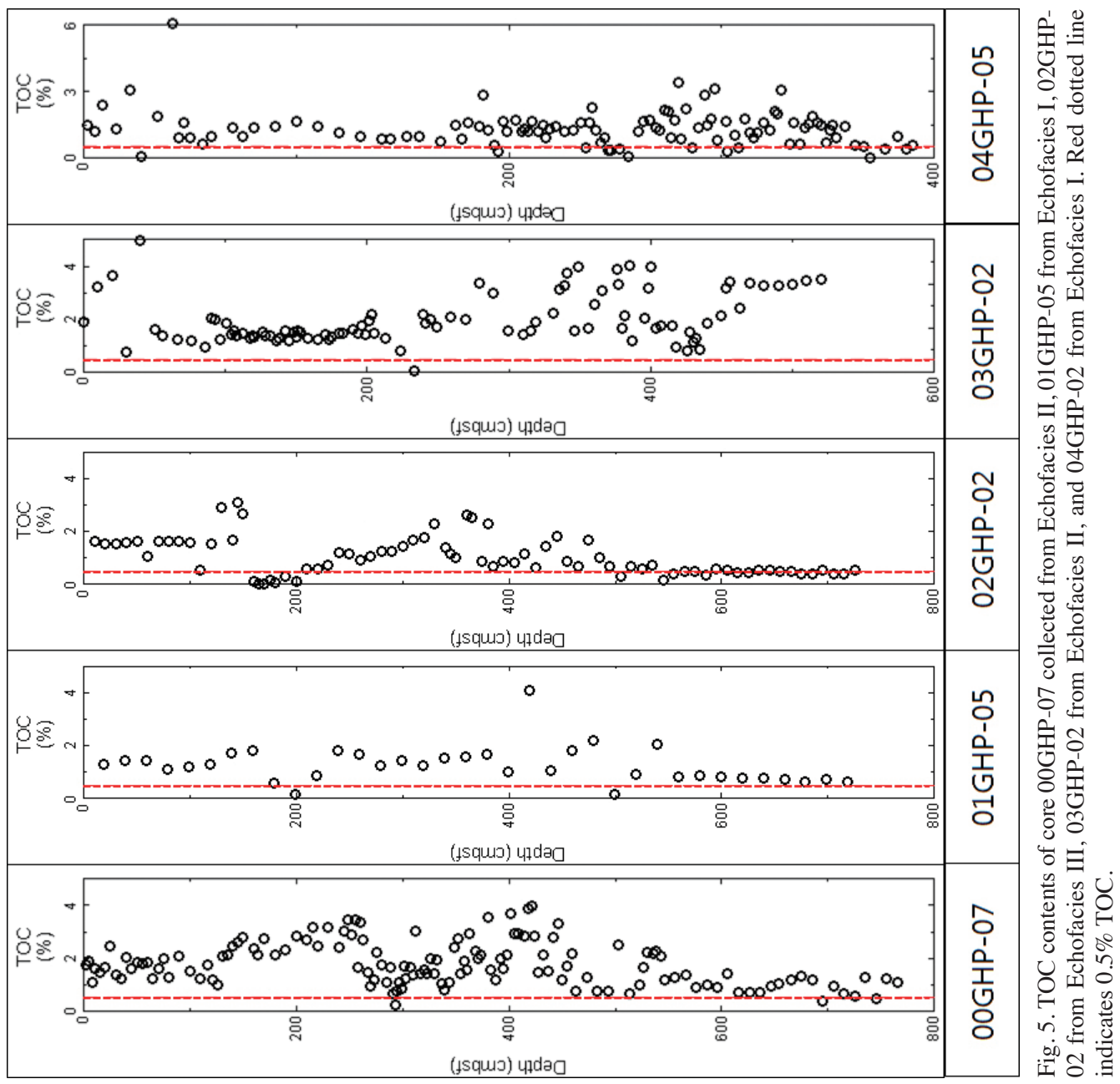

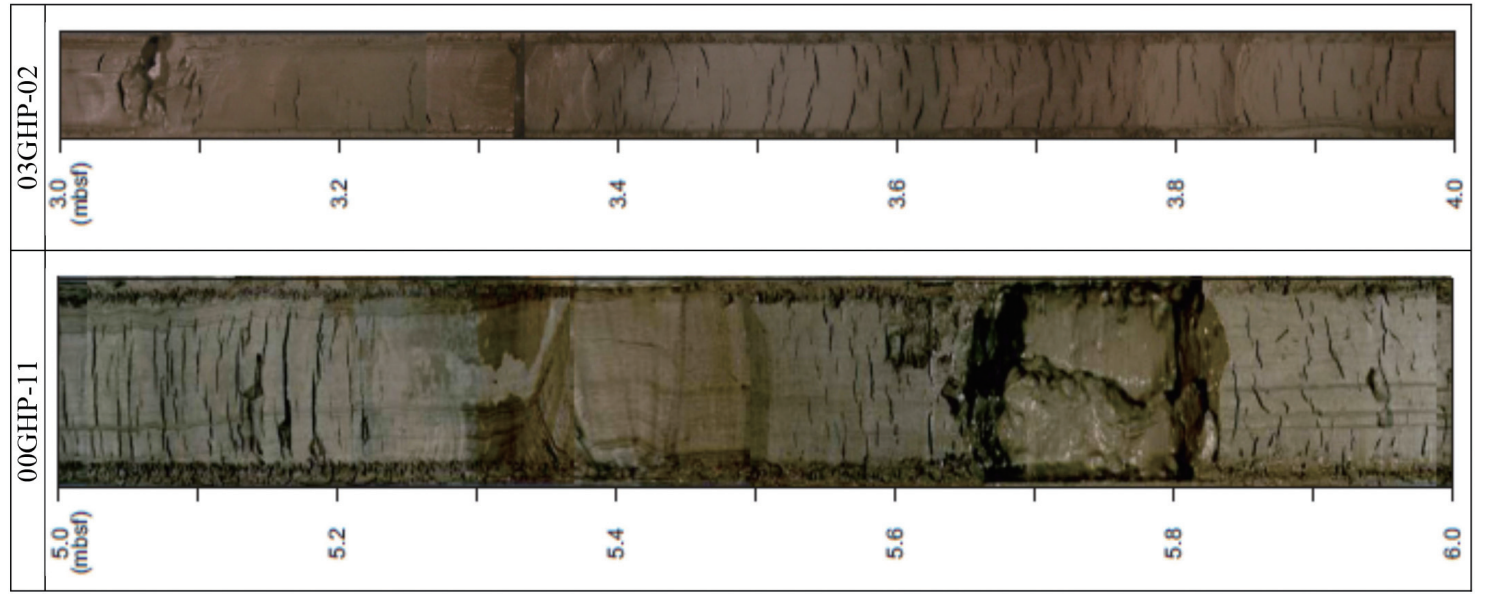




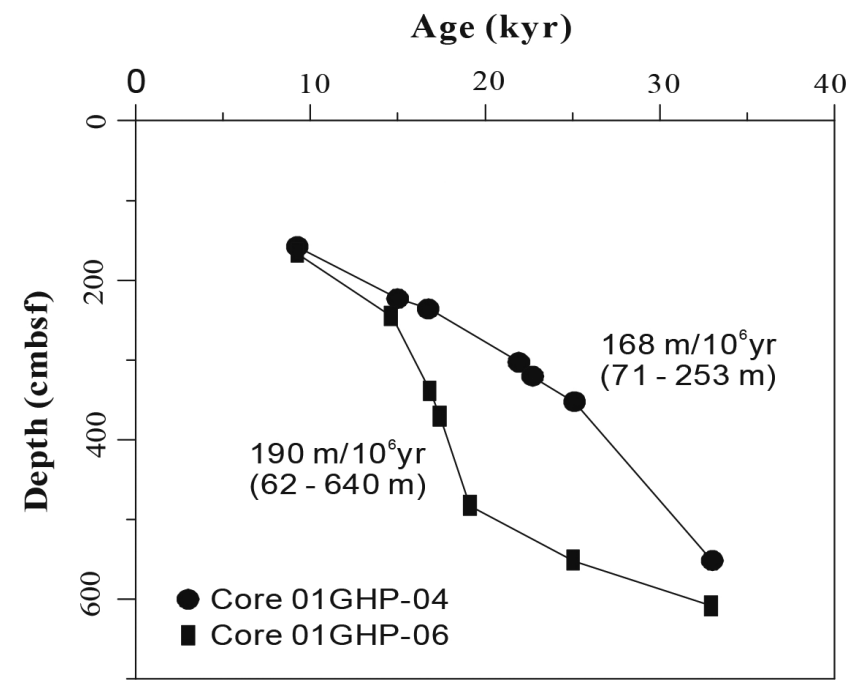

Fig. 6. The variations of sedimentation rates of 01GHP-04 and 01GHP-06 recovered from the basin floor of the Ulleung Basin.

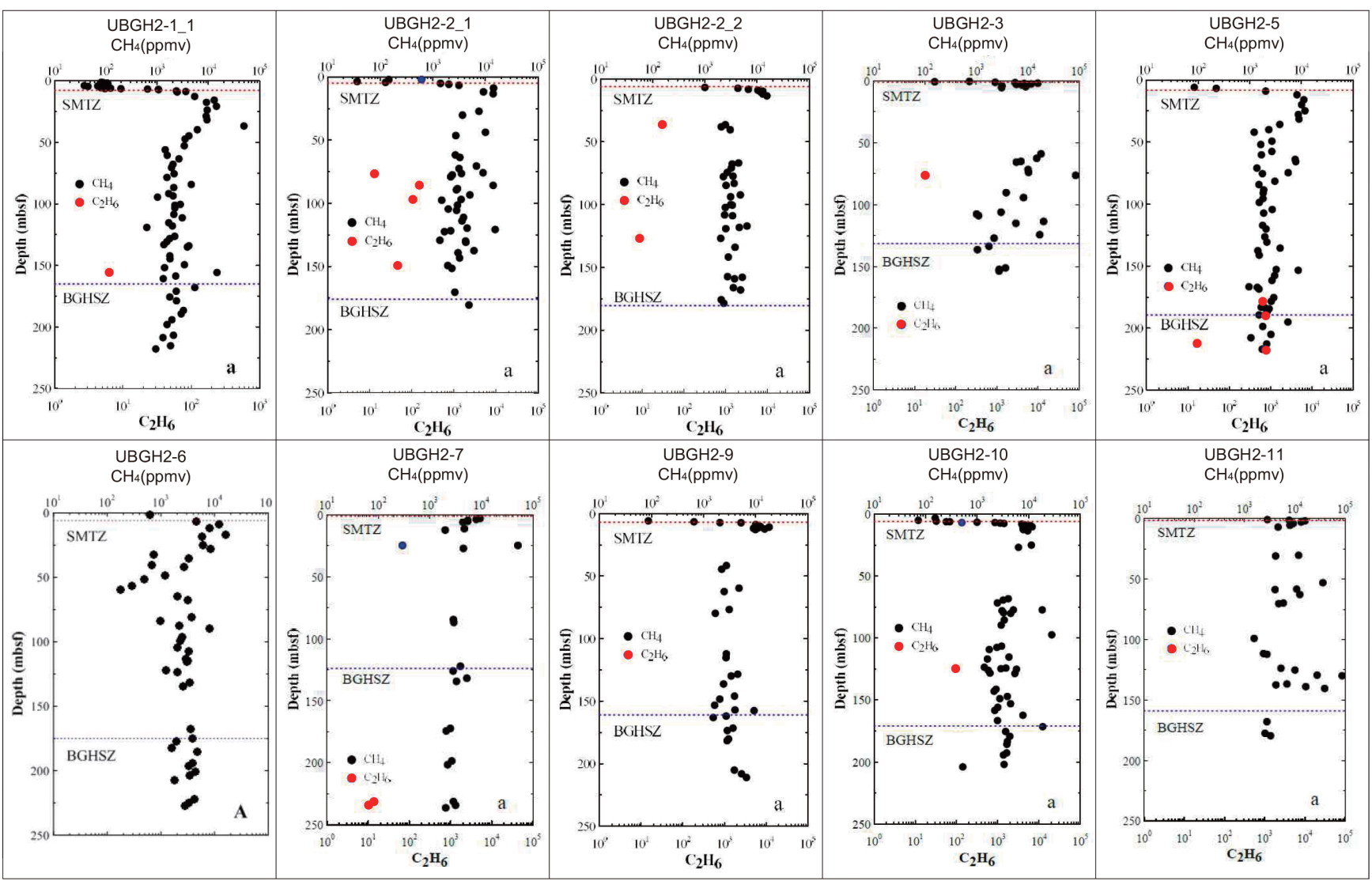

Fig. 7. Downhole profiles of methane and ethane in headspace gases. The red dash line indicates the sulfate-methane transition zone (SMTZ). Note: BGHSZ: Base of Gas Hydrate Stability Zone. 
the approach outlined by Sloan (1998). Spatial variations of residual hydrocarbon showed higher concentration in the southern part than in the northern part of the Ulleung Basin. Also, residual hydrocarbon shows an increasing trend with sediment depth.

\subsection{Gas Composition}

To clarify the gas source by the gas molecular compositions, and to investigate gas migration pathways, headspace gas samples were collected and analyzed from the piston cores (as well as all cores from the drilling expeditions, e.g., Choi et al. 2013). The hydrocarbon gases in sediments are mainly composed of methane, and minor amount ethane was detected (Fig. 7). $\mathrm{C}_{1} / \mathrm{C}_{2}$ ratio and carbon isotopic composition of the methane $\left(\delta^{13} \mathrm{C}_{\mathrm{CH} 4}\right)$ analyzed using piston and $\mathrm{UBGH} 2$ cores indicate that their origin is primarily biogenic (e.g., Sloan 1998).

\subsection{Sulfate-Methane Transition Zone}

The analysis of sulfate concentrations from interstitial waters samples from the piston cores showed a variation of the sulfate-methane transition zone (SMTZ) depth between 3.2 and 13 mbsf, and an increasing trend with geographical latitude (Fig. 7). Thus, sulfate reduction, anaerobic methane oxidation, and methanogenesis are occurring at different depths in these cores basically as a function of the SMTZdepths. Shallow sulfate reduction, and anaerobic methane oxidation occurre in cores 03GHP-01 and 03GHP-02 as their recovered core length (Table 3 ) reached well below the SMTZ. Methanogenesis occurs at greater depths within these two cores after all sulfate is depleted. Meanwhile, only sulfate reduction is dominant in all other cores because their recovered core length did not reach to the SMTZ (Fig. 7). Therefore, the amounts of residual hydrocarbon are higher in cores 03GHP-01 and 03GHP-02 than in the other cores of the 2003 study region. These results suggest that reduction stage in the sediments with high residual hydrocarbon gas could be reached to the depth-interval where methanogenesis is happening, whereas only sulfate reduction is dominant or methanogenesis is shifted to greater depths in the cores with low residual hydrocarbon. Overall, the SMTZ depths in the northern part of the basin are shallower than that in southern basin. It indicates that methane flux in northern basin is higher than in southern basin following basic model developed by Borowski et al. (1996).

\subsection{Geophysical Indicators of Gas Hydrate}

\subsubsection{Seismic Velocity Structure and BSRs}

Across the Ulleung Basin, BSRs were found in a number of local patches (Fig. 8). They occur mainly in the southern part of the basin where mass flow deposits (echofacies
II) are widely developed. They also locally observed in the central part of the study area. However, it appears that in regions of dense occurrence of blank zones (chimneys), no clear BSR is developed. BSR-distribution maps for smaller sub-sets of seismic data across the Ulleung Basin were previously published by Horozal et al. (2009) and Yoo et al. (2013). Our regional coverage (Fig. 8) shows for the first time data north of the Ulleung Island and north of all drilling sites of UBGH1 and UBGH2.

The observed BSRs were characterized by (1) polarity reverse nature relative to the seafloor, (2) seafloor-parallel reflections at sub-bottom depth corresponding to the expected base of gas hydrate stability zone (BGHSZ) as determined from thermal modeling, and (3) marked changes in seismic velocity, with slightly lower values below the BSR. These features are consistent with the BSR being produced by free gas accumulations trapped by gas hydrates at the BGHSZ. The reflection coefficient of the BSR is useful for the estimation of the associated impedance and velocity contrasts, which provide some qualitative constraint on the amounts of gas hydrate and free gas (e.g., Fink and Spence 1999; Yuan et al. 1999). In low-frequency multichannel seismic data $(60-80 \mathrm{~Hz})$, the BSR reflection is consistent with a simple single interface model for the BSR, where the decrease in seismic impedance occurs over a depth range less than the seismic wavelength (about $30 \mathrm{~m}$ for the multichannel seismic data acquired in the Ulleung Basin average velocities of $\sim 1800 \mathrm{~m} \mathrm{~s}^{-1}$ and dominant frequencies of $\sim 60 \mathrm{~Hz}$ ). In several areas, a velocity decrease below the BSRs was found by prestack semblance velocity analyses, although the concentrations of free gas are probably small. AVO studies (e.g., Yi et al. 2011), and band-limited impedance inversion constrained the velocity decrease to mostly $<100 \mathrm{~m} \mathrm{~s}^{-1}$ (Ryu et al. 2009) across the phase boundary for most examples studied.

In the southwestern part of the 2001 survey area at Site UBGH2-6, a strong lateral consistent BSR was observed associated with an anticline structure. Here, the high reflection coefficients reported by Ryu et al. (2009) were confirmed by drilling to be the result of higher gas hydrate concentrations above the interface, with relatively small amounts of free gas (velocity decrease $\sim 100 \mathrm{~m} \mathrm{~s}^{-1}$ ) beneath. However, the sedimentary layers in the study area are often bedded parallel to the seafloor (compare to discussion of seismic- and echofacies) so that the hydrate-related BSR may be hidden.

An important requirement for estimating gas hydrate and free gas concentrations from velocity data is the no hydrate-/gas reference velocity-depth. For the reference velocity-depth (Ryu et al. 2009) interpolated the trend at greater depths well below the BSR with velocity obtained near the seafloor where we assume that there is little hydrate expected (except for chimney structures). That there is little hydrate near the seafloor outside of chimney structures is well supported by well-log velocity data (Kim et al. 2008a, b, 2013a). The semblance-velocity method can be used best if 


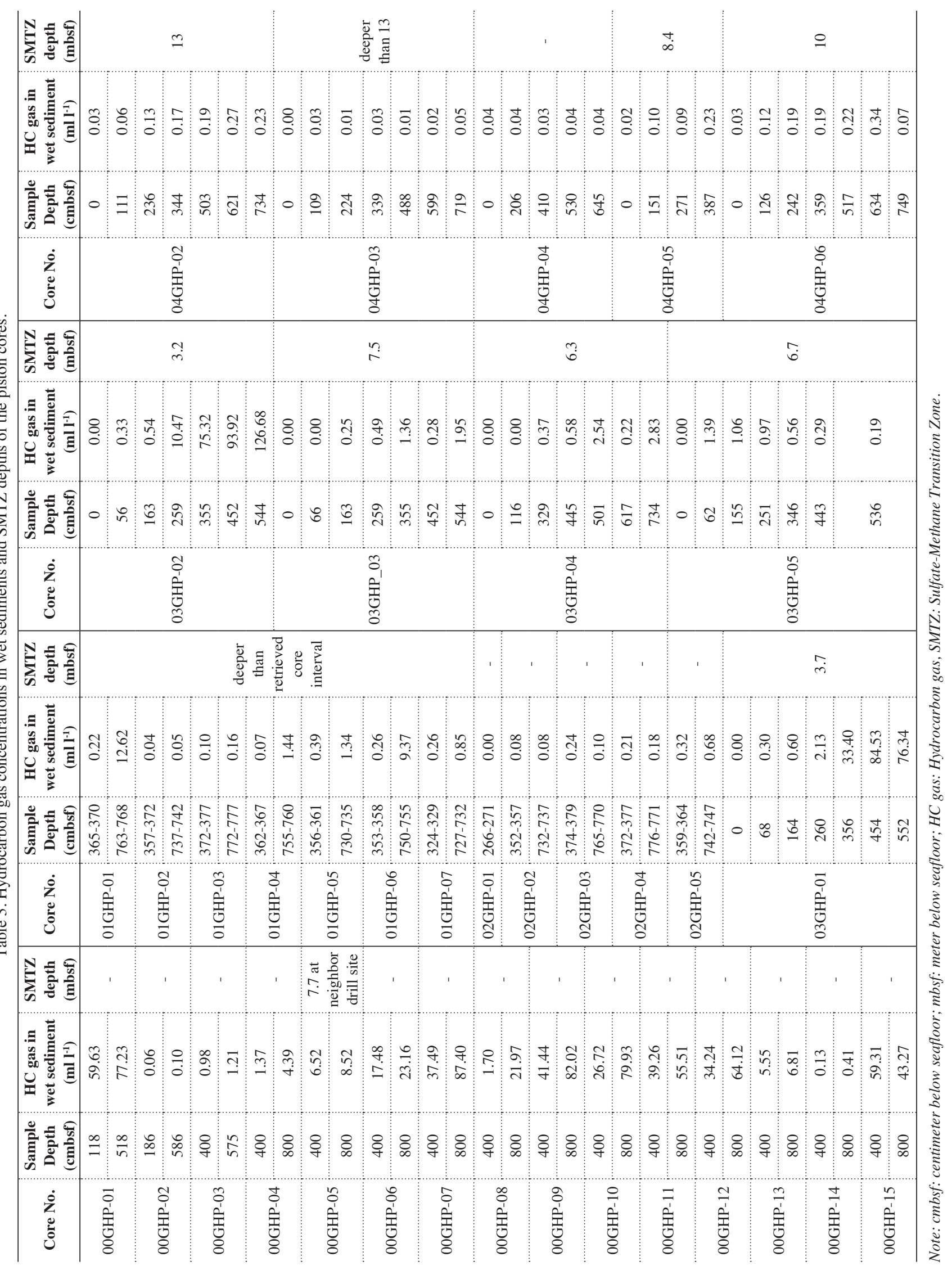




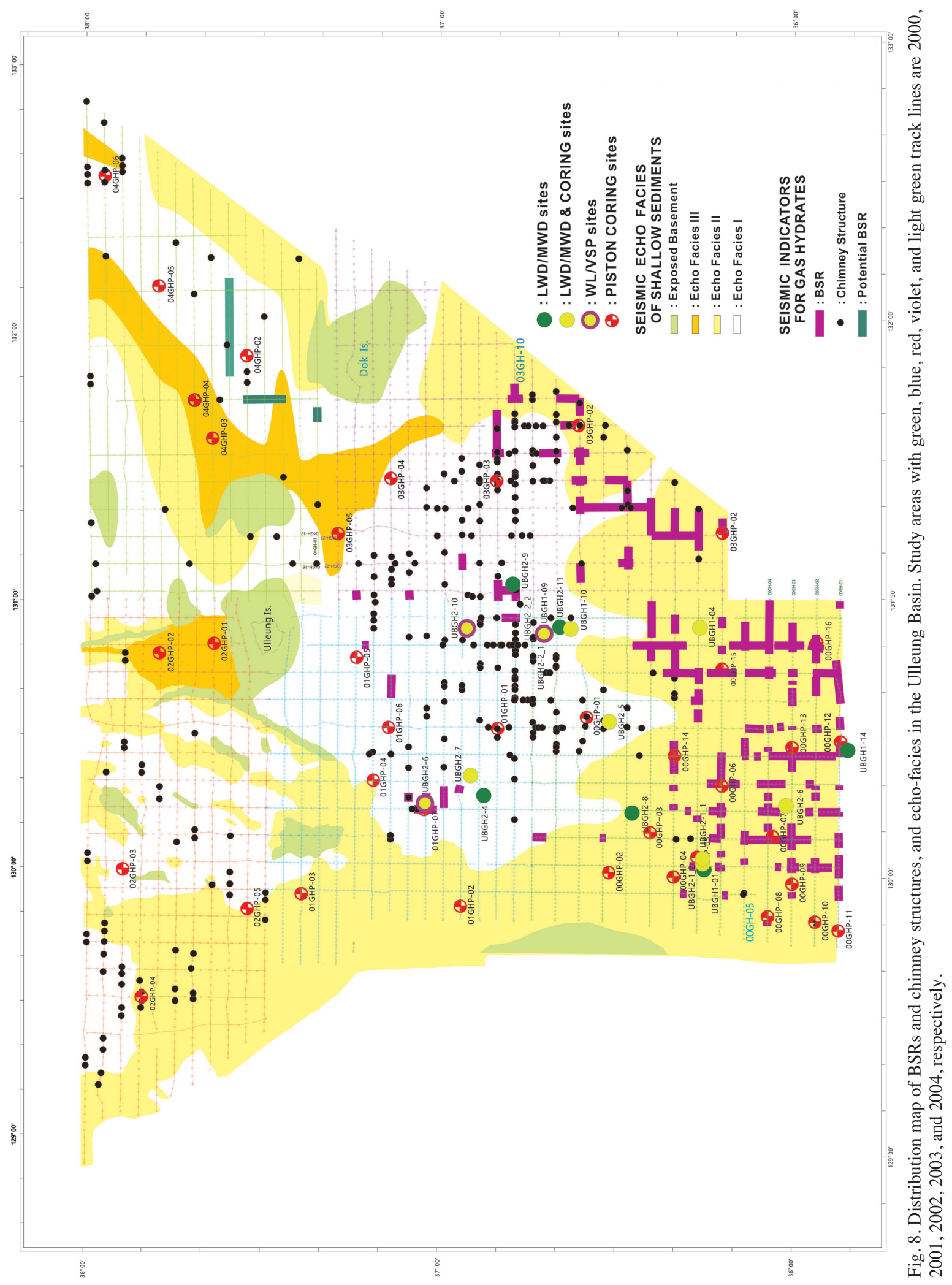


the sediment sections are reasonably homogeneous laterally and on a seismic wavelength scale vertically, with velocity increasing smoothly with depth (time). A stated by Ryu et al. (2009), the reference velocity-depth function was found to be quite constant for large regions of the deep Ulleung Basin, which is also reflected in the nature of the uppermost seismic facies defined (see discussion below). The regional velocity-depth relation defined by Ryu et al. (2009) are in general agreement with those from OBS refraction seismic experiments in the region according to Kim et al. (1998) and well-log data acquired during UBGH1 and UBGH2. Significant deviations from this reference velocity-depth profile may be interpreted as due to high velocity gas hydrate or low velocity free gas, although velocity variations due to lateral changes in sediment type [e.g., in regions of wide-spread mass-transport deposits, where sediment consolidation cannot be excluded (see discussion in Riedel et al. 2012)]. A different approach to defining a reference profile was shown by Kim et al. (2013b) using effective medium modelling for well-log data from UBGH2, based on core-derived distributions of the mineralogy to calculate a site-specific hydrate-free background trend.

\subsubsection{Seismic- and Echofacies of the Sedimentary Strata}

Using facies classification of seismic or acoustic subbottom profiler data is a common approach in regional resource assessments. The principle goal of facies classification is the reduction of seismic data (with complex phase and amplitude information) to simple groups of "similarlooking" data. Several such studies were undertaken for the Ulleung Basin in the past. Using probabilistic classification tools, Kang et al. (2012) defined five seismic facies, which were then verified with the LWD and wire-line log data from the drilling expeditions and incorporated into a resource-type assessment (see section 5.5 for details). Additional seismic facies classifications were carried out by Riedel et al. (2013a, b) for a sub-set of the seismic data and well sites with an aim to improve seismic-based estimation of hydrate concentrations. Yoo et al. (2013) also used seismic facies classifications for resource estimation, and classified the seismic facies into five facies using reflection pattern such as stratified and chaotic, and strength of amplitude.

Here, we present a map of regional echofacies classification (Fig. 8) using the 2D multichannel seismic data collected from 2000 - 2004. The sedimentary strata in the Ulleung Basin and South Korea Plateau located north of the Ulleung Basin are classified into three echofacies in terms of the seismic reflection signatures (Figs. 3 and 8). Echofacies I is characterized by continuous, well-stratified reflections and sheet-shaped sediment depositional geometries (Fig. 3a). This facies unit is present in the strata of a low-gradient slope or the upper strata of the central basin. The region of echofacies I also includes a region of acoustic structures of pock marks and chimney structures in the center of the basin. The unit is interpreted as alternations of very thin turbidite and hemipelagic deposits. Echofacies II mainly occurs in strata at the base of the continental to the south and west of the basin (Fig. 8). The facies unit II represents discontinuous, chaotic or transparent seismic reflection configurations (Fig. 3b). This unit contains commonly hummocky facies in various scales, and is generally very thick. This facies unit partly includes thin layers of stratified reflections. This unit is interpreted as debrites or volcanic or volcanoclastic flow deposits. Echofacies III occurs around the Korea Gap (Fig. 8), and is characterizing by strong erosion from bottom currents or turbidity (or debris) flows (Fig. 3c).

\subsection{Resource Assessments, Production Test Model, and Geotechnical Properties}

Only few sand layers with gas hydrate were recovered during the two drilling expeditions within the Ulleung Basin (Ryu et al. 2012, 2013; Bahk et al. 2013a, b). Resource assessments type studies were subsequently conducted using the drilling data combined with 2D (Riedel et al. 2013a, b) and 3D seismic data (Kim et al. 2015, 2017) in smaller subregions of the basin. A basin-wide assessment was carried out by Ryu et al. (2014). Using Monte Carlo simulations, a resource assessment was performed based on WL/VSP data from three sites (one UBGH1 site and two UBGH2 sites), results of core analyses from 13 sites (three UBGH1 sites and ten UBGH2 sites), $6690 \mathrm{~km}$ of 2D multichannel reflection seismic lines collected in 2005 , and $700 \mathrm{~km}^{2}$ of 3D seismic data acquired in 2006 and 2008 (Ryu et al. 2013). Five facies were classified based on seismic facies, lithofacies, $\log$ facies, and results of core analyses and gas hydrate saturation values $\left(S_{h}\right)$. Each facies was characterized by various parameters (total volume, porosity, net to gross ratio, $S_{h}$, cage occupancy, and volume ratio). The ratios of net thickness of gas hydrate-bearing sand layers to the total thickness of gas hydrate-bearing intervals were determined following the approach of Fujii et al. (2008). The targets of the production test in the Ulleung Basin are gas hydrate-bearing sand layers, which were identified from the UBGH2 sites and are regarded as recoverable resource with existing technologies (Boswell 2009). The in-place gas hydrate resource volume within the sand reservoirs was additionally assessed. The total amount of mean in-place gas resource contained in the gas hydrates within the survey area was estimated to be 58.75 trillion cubic feet (tcf). The mean in-place gas hydrate resource volume within the sand reservoirs was estimated to be 31.16 tcf. Using the data from the two drilling expeditions, significant improvements of the understanding of changes in sediment physical properties due to production were made. Lee et al. (2013) showed that subsidence induced by pore pressure changes as result of depressurization would be greater than changes induced by the loss of gas 
hydrate in the reservoir itself. They also predicted significant vertical deformation in fine-grained sediment layers as a response to the pore pressure changes from depressurization. They further highlighted concerns associated with low fracture gradients in these shallow sedimentary sections. As shown by an earlier study (Kim et al. 2013c), the finegrained sedimentary sections were classified as high plastic silty soils according to the Unified Soil Classification System (USCS); they exhibited high compressibility when subjected to an increase in effective stress (or a decrease in pore water pressure) and had low hydraulic conductivities and low pressure diffusion coefficients. Similar to the analyses by Kim et al. (2013c) and Lee et al. (2013) predicted that the application of depressurization for gas hydrate production would cause a significant amount of sediment compaction. Lee et al. (2013) documented that the sediments in the basin consists mineralogically of illite, kaolinite, chlorite, calcite, and montmorillonite, with a high concentration of microfossils (diatoms). They also argue that the presence of microfossils may affect many of the geotechnical properties, including plasticity, activity, surface area, and grain size.

Following these fundamental analyses, several model scenarios for potential production were computed for the region around Site UBGH2-6 (Moridis et al. 2014). Modeling of the short-term (14 day) and long-term production tests focused (among other scenarios) on the expected gas production rates and the possibility of subsidence and geomechanical stability around the wellbore and within the reservoir, coupled with an overall sensitivity analysis of the assumed gas hydrate system to various flow, thermal, and geomechanical properties of the sediments.

\section{CONCLUSIONS}

The studies on gas hydrates in the deep-water Ulleung Basin, East Sea of Korea using geophysical data, shallow coring, deep drilling, resource assessments, and gas hydrate production modeling, have given the following general results:

(1) Geological and geochemical data of shallow piston cores as well as cores taken during deep drilling support the general interpretation of wide-spread gas hydrate occurrence in the Ulleung Basin. In cores, high amounts of total organic carbon (TOC) and high core headspace gas indicate generally favorable conditions for gas hydrate formation in the shallow sediments. The lack of higher hydrocarbons and the $\delta^{13} \mathrm{C}_{\mathrm{CH} 4}$ values indicate that the methane is primarily of biogenic origin. The SMTZ depths are shallower in the northern basin than within the southern basin, suggesting higher methane fluxes in the northern region. TOC/N and TOC/S ratios and $\delta^{13} \mathrm{C}_{\text {org }}$ values of the core sediments indicate that organic matters are dominantly originated from marine algae.

(2) Bottom-simulating reflectors (BSRs) were identified across the Ulleung Basin from a dense grid of 2 D seismic data by (a) polarity reversed nature relative to the seafloor, (b) seafloor-parallel reflection behavior, and (c) occurrences at a sub-bottom depth corresponding to the expected BGHSZ. Their occurrences are patchy and the reflection amplitude is generally low indicating small amounts of free gas below the BGHSZ. The BSRs were used primarily as general guide for mapping gas hydrate occurrences within the basin, but are not the only direct gas hydrate indicator in the region.

(3) Vertical to sub-vertical seismic blanking zones are well observed throughout the Ulleung Basin. The blanking zones (with more than 250 structures identified on 2D seismic lines alone) are near-vertical broad chimney structures of reduced sediment layering reflectivity. They may be formed by gas and/or fluid upwelling through fractures and faults. Many of the blanking zones show apparent velocity pull-up structures in time-migrated seismic data which are interpreted to be a result of higher velocity gas hydrate. The presence of substantial amounts of gas hydrates in the blanking zones was confirmed by piston coring in 2007 , and two drilling expeditions in 2007 and 2010. The blanking zones mainly occur in the hemi-pelagic/turbidte facies developed in the central part of the basin. They also are locally observed in the northern basin (e.g., Site UBGH2-7) or isolated along the southern edge of the basin (e.g., Site UBGH2$3)$. Although no production technology has yet been identified for these chimney structures, they represent, when regionally combined, the largest accumulation of gas hydrate in the Ulleung Basin and thus, may represent a valuable resource.

(4) To characterize the distribution of gas hydrate indicators in the Ulleung Basin, shallow echofacies and seismic facies were analyzed based on seismic reflection signatures. These echofacies reflect regional depositional characters and sediment distribution and were facilitated in regional resource assessments.

(5) Gas hydrate saturations were determined from geophysical well-log data as well as pore-water chemistry and core infra-red imaging. Saturation estimates vary significantly between drill/core sites, but are generally consistent at each individual site between acoustic and resistivity-based approaches.

(6) The combined use of geophysical image logs and pressure coring revealed that gas hydrate occurs in a fracture network within the seismic blanking zones. Saturation estimates from well-logs have to consider the anisotropy effect imposed by the near-vertical fracture network being parallel to the vertical well-log tool measurements.

(7) The dense grid of 2D seismic profiles across the basin, combined with the coverage of multibeam and high-resolution echosounder data in conjunction with two comprehensive drilling expeditions allowed careful resource 
assessments for the Ulleung Basin. Facies classification, complete core-log-seismic integration, and petroleum system modeling demonstrated a potential of the Ulleung Basin to host substantial amounts of gas hydrates.

\section{FUTURE RESEARCH AND DIRECTION}

With the successful completion of the UBGH2, the primary goals of the gas hydrate development project were sufficiently accomplished. A production test primarily was planned to be performed in 2015. For safer and more successful testing, additional studies of seafloor stability, rehydration and sand-production problems are required. Thus, the production test has been postponed to the period of the $2^{\text {nd }}$ gas hydrate $R \& D$ program that is currently being planned. To develop the most suitable techniques for the production, experimental researches will be performed using a 3D mscale simulator. To ensure safe and environmental friendly production testing, environmental impact studies including baseline and monitoring surveys have been and will continue to be performed in the future. A first baseline survey has been performed using the KIGAM Seafloor Observation System (KISOS). To monitor the various potential hazards associated with the dissociated gas from gas hydrates, a monitoring survey will be performed using the KIGAM Seafloor Monitoring System (KIMOS) during the proposed production test. Geophysical surveys for determining any changes of the gas hydrate reservoirs and production-efficiency around the production well will also be conducted before and after the production test.

Acknowledgements This paper was supported by the research project of the Korea Institute of Geoscience and Mineral Resources (Gas Hydrate Exploration and Development Study) supported by the Ministry of Science, ICT and Future Planning (currently Ministry of Science and ICT). We sincerely thank the scientists and technical staffs working for this gas hydrate project at the KIGAM, and crew of $R / V$ TAMHAE II responsible for the geophysical data acquisition and core recovery.

\section{REFERENCES}

Archer, D., 2007: Methane hydrate stability and anthropogenic climate change. Biogeosciences, 4, 521-544, doi: 10.5194/bg-4-521-2007. [Link]

Bahk, J. J., D. H. Kim, J. H. Chun, B. K. Son, J. H. Kim, B. J. Ryu, M. E. Torres, M. Riedel, and P. Schultheiss, 2013a: Gas hydrate occurrences and their relation to host sediment properties: Results from Second Ulleung Basin Gas Hydrate Drilling Expedition, East Sea. Mar. Petrol. Geol., 47, 21-29, doi: 10.1016/j.marpetgeo.2013.05.006. [Link]

Bahk, J. J., G. Y. Kim, J. H. Chun, J. H. Kim, J. Y. Lee, B.
J. Ryu, J. H. Lee, B. K. Son, and T. S. Collett, 2013b: Characterization of gas hydrate reservoirs by integration of core and log data in the Ulleung Basin, East Sea. Mar. Petrol. Geol., 47, 30-42, doi: 10.1016/j.marpetgeo.2013.05.007. [Link]

Borowski, W. S., C. K. Paull, and W. Ussler, 1996: Marine pore-water sulfate profiles indicate in situ methane flux from underlying gas hydrate. Geology, 24, 655658, doi: 10.1130/0091-7613(1996)024<0655:MPWS$\mathrm{PI}>2.3 . \mathrm{CO} ; 2$. [Link]

Boswell, R., 2009: Is hydrate energy within reach? Science, 325, 957-958, doi: 10.1126/science.1175074. [Link]

Boswell, R. and T. S. Collett, 2011: Current perspectives on gas hydrate resources. Energy Environ. Sci., 4, 12061215, doi: 10.1039/c0ee00203h. [Link]

Choi, J., J. H. Kim, M. E. Torres, W. L. Hong, J. W. Lee, B. Y. Yi, J. J. Bahk, and K. E. Lee, 2013: Gas origin and migration in the Ulleung Basin, East Sea: Results from the Second Ulleung Basin Gas Hydrate Drilling Expedition (UBGH2). Mar. Petrol. Geol., 47, 113-124, doi: 10.1016/j.marpetgeo.2013.05.022. [Link]

Chough, S.K. and E. Barg, 1987: Tectonic history of Ulleung basin margin, East Sea (Sea of Japan). Geology, 15, 4548, doi: 10.1130/0091-7613(1987)15<45:THOUBM> 2.0.CO;2. [Link]

Chough, S. K., H. J. Lee, and S. H. Yoon, 2000: Marine Geology of Korean Seas, 2nd Ed., Elsvier, Amsterdam, $313 \mathrm{pp}$.

Collett, T. S., A. H. Johnson, C. C. Knapp, and R. Boswell, 2009: Natural Gas Hydrates: A Review. Natural Gas Hydrates - Energy Resource Potential and Associated Geologic Hazards, AAPG Memoir 89, 146-219.

Collett, T. S., M. Riedel, R. Boswell, J. Presley, P. Kumar, A. Sathe, A. Sethi, and M. V. Lall, 2015: Indian National Gas Hydrate Program Expedition 01 report. Scientific Investigations Report 2012-5054, U.S. Geological Survey, Reston, VA, 1442 pp, doi: 10.3133/ sir20125054. [Link]

Fink, C. R. and G. D. Spence, 1999: Hydrate distribution off Vancouver Island from multifrequency single-channel seismic reflection data. J. Geophys. Res., 104, 29092922, doi: 10.1029/98JB02641. [Link]

Furo Mcclelland Marine Geosciences, Inc., 2007: Investigation of Gas Hydrate Expedition UBGH1, Ulleung Basin, East Sea offshore Korea, Factual Field Report No. 0201-6242.

Fujii, T., T. Saeki, T. Kobayashi, T. Inamori, M. Hayashi, O. Takano, T. Takayama, T. Kawasaki, S. Nagakubo, M. Nakamizu, and K. Yokoi, 2008: Resource assessment of methane hydrate in the eastern Nankai Trough, Japan. Proceedings of Offshore Technology Conference, OTC-19310-MS, Houston, Texas, USA , doi: 10.2118/19310-ms. [Link]

Gardner, J. M., A. N. Shor, and W. Y. Jung, 1998: Acoustic 
imagery evidence for methane hydrates in the U1leung Basin. Mar. Geophys. Res., 20, 495-503, doi: 10.1023/A:1004716700055. [Link]

Gieskes, J. M., T. Gamo, and H. Brumsack, 1991: Chemical methods for interstitial water analysis aboard JOIDES Resolution. Ocean Drilling Program Technical Notes 15, College Station, TX (Ocean Drilling Program), 60 pp, doi: 10.2973/odp.tn.15.1991. [Link]

Gorman, A. R., W. S. Holbrook, M. J. Hornbach, K. L. Hackwith, D. Lizarralde, and I. Pecher, 2002: Migration of methane gas through the hydrate stability zone in a low-flux hydrate province. Geology, 30, 327-330, doi: 10.1130/0091-7613(2002)030<0327:MOMGTT> 2.0.CO;2. [Link]

Grevemeyer,I., A. Rosenberger, and H. Villinger, 2000: Natural gas hydrates on the continental slope off Pakistan: Constraints from seismic techniques. Geophys. J. Int., 140, 295-310, doi: 10.1046/j.1365-246x.2000.00009.x. [Link]

Haq, B. U., 2000: Climatic Impact of Natural Gas Hydrate. In: Max, M. D. (Ed.), Natural Gas Hydrate, Coastal Systems and Continental Margins, Vol. 5, Springer, Dordrecht, 137-148, doi: 10.1007/978-94-011-43875_11. [Link]

Horozal, S., G. H. Lee, B. Y. Yi, D. G. Yoo, K. P. Park, H. Y. Lee, W. Kim, H. J. Kim, and K. Lee, 2009: Seismic indicators of gas hydrate and associated gas in the Ulleung Basin, East Sea (Japan Sea) and implications of heat flows derived from depths of the bottom-simulating reflector. Mar. Geol., 258, 126-138, doi: 10.1016/j. margeo.2008.12.004. [Link]

Huh, D.-G., Y. I. Kwon, H.-T. Kim, B.-J. Ryu, K.-S. Park, K.P. Park, S.-Y. Suh, B.-K. Son, W.-C. Shin, J.-H. Oh, H.-Y. Lee, J.-H. Chang, B.-H. Chung, T.-J. Jeong, J.-H. Jin, I.-G. Hwang, N.-H. Koo, I.-K. Kwon, S.-Y. Kim, S.-J. Kim, J.-H. Kim, H.-J. Kim, S.-I. Nam, J.-J. Bahk, D. Sunwoo, N. H. Sung, D.-G. Yoo, Y.-J. Lee, W.-S. Lee, J.-H. Lee, S.-H. Jang, D.-H. Kang, B.-Y. Kim, Y.-G. Kim, W. S. Kim, Y. J. Kim, J. -H. Kim, E.Y. An, K.-D. Hwang, G.-S. Seo, G.-O. An, J.-K. Choi, J.-M. Kang, S.-C. Park, J.-M. Byun, W.-M. Sung, S.Y. Sin, K.-M. Yoo, S.-M. Lee, J.-H. Lee, H. Lee, R. Sassen, and Y. Seol, 2005: Studies on Gas Hydrate Development Technology, KIGAM Research Report, GAD2000011-2005(6), 552 pp. (in Korean)

Hyndman, R. D. and E. E. Davis, 1992: A mechanism for the formation of methane hydrate and seafloor bottomsimulating reflectors by vertical fluid expulsion. J.Geophys. Res., 97, 7025-7041, doi: 10.1029/91JB03061. [Link]

Hyndman, R. D. and G. D. Spence, 1992: A seismic study of methane hydrate marine bottom simulating reflectors. J. Geophys. Res., 97, 6683-6698, doi: 10.1029/92JB00234. [Link]
Hyndman, R. D., K. Wang, T. Yuan, and G. D. Spence, 1993: Tectonic sediment thickening, fluid expulsion, and the thermal regime of subduction zone accretionary prisms: The Cascadia Margin off Vancouver Island. J. Geophys. Res., 98, 21865-21876, doi: 10.1029/93JB02391. [Link]

Jang, S. H., S. Y. Suh, B. H. Chung, and B. J. Ryu, 1999: Seismic data processing for gas hydrate using Geobit. Geophysics and Geophysical Exploration, 2, 184-190. (in Korean)

Jolivet, L., H. Shibuya, and M. Fournier, 1995: Paleomagnetic rotations and the Japan Sea opening. In: Taylor, B. and J. Natland (Eds.), Active Margins and Marginal Basins of the Western Pacific, American Geophysical Union, Washington, D. C., 358-369, doi: 10.1029/ GM088p0355. [Link]

Kang, D. H., J. H. Chun, N. H. Koo, W. S. Kim, and H. Y. Lee, 2015: Consideration on the gas and gas hydrate indicators in seismic profiles based on drilling result from the Ulleung Basin, East Sea. J. Geol. Soc. Korea, 51, 561-568, doi: 10.14770/jgsk.2015.51.6.561. [Link]

Kang, N., D.-G. Yoo, B. Yi, J.-J. Bahk, and B.-J. Ryu, 2012: Resources assessment of gas hydrate in the Ulleung Basin, offshore Korea. American Geophysical Union, Fall Meeting 2012, abstract \#OS31G-02.

Kastner, M., K. A. Kvenvolden, M. J. Whiticar, A. Camerlenghi, and T. D. Lorenson, 1995: Relation between Pore Fluid Chemistry and Gas Hydrates Associated with Bottom-Simulating Reflectors at the Cascadia Margin, Sites 889 and 892. In: Crason, B., G. K. Westbrook, R. J. Musgrave, and E. Suess (Eds.), Proceedings of the Ocean Drilling Program, Scientific Results, Vol. 146 (Pt. 1), College Station, TX (Ocean Drilling Program), 175-187, doi: 10.2973/odp.proc.sr.1461.213.1995. [Link]

Kennett, J. P., K. G. Cannariato, I. L. Hendy, and R. J. Behl, 2003: Methane Hydrates in Quaternary Climate Change: The Clathrate Gun Hypothesis, American Geophysical Union, Washington DC, 216 pp, doi: 10.1029/054SP. [Link]

Kim, G. Y., D. G. Yoo, W. S. Kim, H. Y. Lee, and K. P. Park, 2008a: Gas hydrate exploration using LWD/ MWD in the Ulleung Basin, the East Sea of Korea. Geophysics and Geophysical Exploration, 11, 263270. (in Korean)

Kim, G. Y., D. G. Yoo, W. S. Kim, H. Y. Lee, and K. P. Park, 2008b: Physical properties of gas hydrate-bearing sediments in the Ulleung Basin, the east sea of Korea: Preliminary result from well-log data. 6th International Conference on Gas Hydrates (ICGH 2008), Vancouver, p. 118.

Kim, G. Y., B. Y. Yi, D. G. Yoo, B. J. Ryu, and M. Riedel, 2011: Evidence of gas hydrate from downhole logging data in the Ulleung Basin, East Sea. Mar.Petrol.Geol., 
28, 1979-1985, doi: 10.1016/j.marpetgeo.2011.01.011. [Link]

Kim, G. Y., B. Narantsetseg, B. J. Ryu, D. G. Yoo, J. Y. Lee, H. S. Kim, and M. Riedel, 2013a: Fracture orientation and induced anisotropy of gas hydrate-bearing sediments in seismic chimney-like-structures of the Ulleung Basin, East Sea. Mar. Petrol. Geol., 47, 182194, doi: 10.1016/j.marpetgeo.2013.06.001. [Link]

Kim, H.-J., S.-J. Han, G. H. Lee, and S. Huh, 1998: Seismic study of the Ulleung Basin crust and its implications for the opening of the East Sea (Japan Sea). Mar. Geophys. Res., 20, 219-237, doi: 10.1023/A:1004573816915. [Link]

Kim, H. S., M. Riedel, B. J. Ryu, G. Y. Kim, and J. J. Bahk, 2013b: Improving gas hydrate saturation estimates using P-wave velocity log data by incorporating XRDData for detailed matrix-mineralogy definition. Mar. Petrol. Geol., 47, 155-167, doi: 10.1016/j.marpetgeo.2013.05.020. [Link]

Kim, H. S., G.-C. Cho, J. Y. Lee, and S.-J. Kim, 2013c: Geotechnical and geophysical properties of deep marine fine-grained sediments recovered during the second Ulleung Basin Gas Hydrate expedition, East Sea, Korea. Mar. Petrol. Geol., 47, 56-65, doi: 10.1016/j. marpetgeo.2013.05.009. [Link]

Kim, J. H., M. E. Torres, W. L. Hong, J. Choi, M. Riedel, J. J. Bahk, and S. H. Kim, 2013d: Pore fluid chemistry from the Second Gas Hydrate Drilling Expedition in the Ulleung Basin (UBGH2): Source, mechanisms and consequences of fluid freshening in the central part of the Ulleung Basin, East Sea. Mar. Petrol. Geol., 47, 99-112, doi: 10.1016/j.marpetgeo.2012.12.011. [Link]

Kim, K. J., B. Y. Yi, N. K. Kang, and D. G. Yoo, 2015: Seismic attribute analysis of the indicator for gas hydrate occurrence in the northwest Ulleung Basin, East Sea. Energy Procedia, 76, 463-469, doi: 10.1016/j. egypro.2015.07.882. [Link]

Kim, K. J., B. Y. Yi, N. K. Kang, and D. G. Yoo, 2017: Reservoir characterization of gas hydrate in the Northwestern part of the Ulleung Basin, East Sea. Marine Georesources \& Geotechnology, 35, 226-235, doi: 10.1080/1064119x.2016.1139644. [Link]

Kvenvolden, K. A., 1993: Gas hydrates-geological perspective and global change. Rev. Geophys., 31, 173-187, doi: 10.1029/93RG00268. [Link]

Kvenvolden, K. A. and T. D. Lorenson, 2001: The global occurrence of natural gas hydrate. In: Paull, C. K. and W. P. Dillon (Eds.), Natural Gas Hydrates: Occurrence, Distribution, and Detection, American Geophysical Union, Washington, D. C., 3-18, doi: 10.1029/ gm124p0003. [Link]

Lee, J. H., Y. S. Baek, B. J. Ryu, M. Riedel, and R. D. Hyndman, 2005: A seismic survey to detect natural gas hydrate in the East Sea of Korea. Mar. Geophys. Res., 26,
51-59, doi: 10.1007/s11001-005-6975-4. [Link]

Lee, J. Y., G.-Y. Kim, N. K. Kang, B.-Y. Yi, J. W. Jung, J.-H. Im, B.-K. Son, J.-J. Bahk, J.-H. Chun, B.-J. Ryu, and D. S. Kim, 2013: Physical properties of sediments from the Ulleung Basin, East Sea: Results from Second Ulleung Basin Gas Hydrate Drilling Expedition, East Sea (Korea). Mar. Petrol. Geol., 47, 43-55, doi: 10.1016/j.marpetgeo.2013.05.017. [Link]

Lee, M. W. and T. S. Collett, 2013a: Characteristics and interpretation of fracture-filled gas hydrate - An example from the Ulleung Basin, East Sea of Korea. Mar. Petrol. Geol., 47, 168-181, doi: 10.1016/j.marpetgeo.2012.09.003. [Link]

Lee, M. W. and T. S. Collett, 2013b: Scale-dependent gas hydrate saturation estimates in sand reservoirs in the Ulleung Basin, East Sea of Korea. Mar. Petrol. Geol., 47, 195-203, doi: 10.1016/j.marpetgeo.2012.09.004. [Link]

Long, P. E., M. Riedel, A. M. Truhe, T. Collett, J. Weinberger, M. Torres, F. Rack, G. Bohrmann, and Shipboard Scientific Party, Leg 204, 2003: Abundance and texture of gas hydrate beneath Hydrate Ridge, offshore Oregon, USA from infrared imaging. EGS - AGU EUG Joint Assembly, Abstracts from the meeting held in Nice, France, 6 - 11 April 2003, abstract \#7999.

MacDonald, G. J., 1990: Role of methane clathrates in past and future climates. Clim. Change, 16, 247-281, doi: 10.1007/bf00144504. [Link]

Makogon, Y.F., 1997: Hydrates of Hydrocarbons, PennWell Publishing Company, Tulsa, Oklahoma, 482 pp.

Maslin, M., M. Owen, R. Betts, S. Day, T. Dunkley Jones, and A. Ridgwell, 2010: Gas hydrates: Past and future geohazard? Phil. Trans. Math. Phys. Eng. Sci., 368, 2369-2393, doi: 10.1098/rsta.2010.0065. [Link]

Matsumoto, R., Y. Okuda, and Y. Aoki, 1994: Huge Natural Gas Resource of the $21^{\text {st }}$ Century, Nihon Keizai Shimbun, Tokyo, 253 pp. (in Japanese)

McIver,R.D., 1982: Role of naturally occurring gas hydrates in sediment transport. AAPG Bull., 66, 789-792, doi: 10.1306/03b5a318-16d1-11d7-8645000102c1865d. [Link]

Moridis, G. J., J. Kim, M. T. Reagan, and S. J. Kim, 2014: System Response During Short- and Long-Term Gas Production from a Gas Hydrate Deposit at the Site of a Planned Field Test in the Ulleung Basin of the Korean East Sea. Offshore Technology Conference, Paper OTC 25384, Houston, Texas, doi: 10.4043/25384-ms. [Link]

Moriyasu, S., 1972: The Tsushima Current. In: Stommel, H. and K. Yoshida (Eds.), Kuroshio, Its Physical Aspects, Univ. of Tokyo Press, 353-369.

Park, K. P., J.-J. Bahk, Y. Kwon, G. Y. Kim, M. Riedel, M. Holland, P. Schultheiss, K. Rose, and the UBGH-1 scientific party, 2008: Korean national program expedition 
confirms rich gas hydrate deposit in the Ulleung Basin, East Sea. Fire in the Ice, NETL Methane Hydrate Newsletter, Spring 2008, 6-9.

Park, K.P., J.-J. Bahk, M. Holland, T.-S. Yun, P.Svhultheiss, and C. Santamarina, 2009: Improved pressure core analysis provides detailed look at Korean cores. Fire in the Ice, NETL Methane Hydrate Newsletter, Winter 2009, 18-20.

Park, M. H., J. H. Kim, I. S. Kim, B. J. Ryu, and K. M. Yu, 2005: Tephrostratigraphy and paleo-environmental implications of Late Quaternary sediments and interstitial water in the western Ulleung Basin, East/Japan Sea. Geo-Mar. Lett., 25, 54-62, doi: 10.1007/s00367004-0203-0. [Link]

Park, S. J., S. H. Yoon, and S. K. Chough, 2002: Evolution of sedimentary basin in the SW Ulleung Basin margin East Sea (Sea of Japan). Proc. of Korea-Japan Symp., Possible Collaboration on East Sea (Sea of Japan) Scientific Drilling between Korea and Japan in Relation to Integrated Ocean Drilling Program (IODP), Gyeongju, 83-99.

Paull, C. K., R. Matusmoto, and P. J. Wallace, 1997: Proceedings of the Ocean Drilling Program, Initial Reports, Vol. 164, College Station, TX (Ocean Drilling Program), 623 pp, doi: 10.2973/odp.proc.ir.164.1996. [Link]

Paull, C. K., W. Ussler, and W. P. Dillon, 2000a: Potential role of gas hydrate decomposition in generating submarine slope failures. In: Max, M. D. (Ed.), Natural Gas Hydrate, Coastal Systems and Continental Margins, Vol. 5, Springer, Dordrecht, 149-156, doi: 10.1007/978-94-011-4387-5_12. [Link]

Paull, C. K., T. D. Lorenson, W. S. Borowski, W. I. Ussler, K. Olsen, and N. M. Rodriguez, 2000b: Isotopic composition of $\mathrm{CH}_{4}, \mathrm{CO}_{2}$ species, and sedimentary organic matter within samples from the Blake Ridge: gas source implications. In: Paull, C. K., R. Matsumoto, P. J. Wallace, and W. P. Dillon (Eds.), Proceedings of the Ocean Drilling Program, Scientific Results, Vol. 164, College Station, TX (Ocean Drilling Program), 67-78, doi: 10.2973/odp.proc.sr.164.207.2000. [Link]

Peters, K. E., 1986: Guidelines for evaluating petroleum source rock using programmed pyrolysis. AAPG Bull., 70, 318-329, doi: 10.1306/94885688-1704-11d78645000102c1865d. [Link]

Petersen, C. J., S. Bünz, S. Hustoft, J. Mienert, and D. Klaeschen, 2010: High-resolution P-Cable 3D seismic imaging of gas chimney structures in gas hydrated sediments of an Arctic sediment drift. Mar. Petrol. Geol., 27, 1981-1994, doi: 10.1016/j.marpetgeo.2010.06.006. [Link]

Pimmel, A. and G. Claypool, 2001: Introduction to shipboard organic geochemistry on the JOIDES Resolution. Ocean Drilling Program Technical Notes 30, Col- lege Station, TX, 29 pp, doi: 10.2973/odp.tn.30.2001. [Link]

Riedel, M., G. D. Spence, N. R. Chapman, and R. D. Hyndman, 2002: Seismic investigations of a vent field associated with gas hydrates, offshore Vancouver Island. J. Geophys. Res., 107, doi: 10.1029/2001JB000269. [Link]

Riedel, M., P. Long, C. S. Liu, P. Schultheiss, T. Collett, and ODP Leg 204 Shipboard Scientific Party, 2006a: Physical properties of near-surface sediments at Southern Hydrate Ridge: Results from ODP Leg 204. In: Tréhu, A. M., G. Bohrmann, M. E. Torres, and F. S. Colwell (Eds.), Proceedings of the Ocean Drilling Program, Scientific Results, Vol. 204, College Station, TX (Ocean Drilling Program), 1-29, doi: 10.2973/odp. proc.sr.204.104.2006. [Link]

Riedel, M., T. S. Collett, M. J. Malone, and the Expedition 311 Scientists, 2006b: Expedition 311 summary. Proceedings of the IODP, Washington, DC (Integrated Ocean Drilling Program Management International, Inc.), doi: 10.2204/iodp.proc.311.101.2006. [Link]

Riedel, M., J.-J. Bahk, N. A. Scholz, B.-J. Ryu, D.-G. Yoo, W. Kim, and G. Y. Kim, 2012: Mass-transport deposits and gas hydrate occurrences in the Ulleung Basin, East Sea - Part 2: Gas hydrate content and fractureinduced anisotropy. Mar. Petrol. Geol., 35, 75-90, doi: 10.1016/j.marpetgeo.2012.03.005. [Link]

Riedel, M., J. J. Bahk, H. S. Kim, D. G. Yoo, W. S. Kim, and B. J. Ryu, 2013a: Seismic facies analyses as aid in regional gas hydrate assessments. Part-I: Classification analyses. Mar. Petrol. Geol., 47, 248-268, doi: 10.1016/j.marpetgeo.2013.04.011. [Link]

Riedel, M., J. J. Bahk, H. S. Kim, N. A. Scholz, D. G. Yoo, W. S. Kim, B. J. Ryu, and S. R. Lee, 2013b: Seismic facies analyses as aid in regional gas hydrate assessments. Part-II: Prediction of reservoir properties, gas hydrate petroleum system analysis, and Monte Carlo simulation. Mar. Petrol. Geol., 47, 269-290, doi: 10.1016/j.marpetgeo.2013.04.012. [Link]

Ryu, B. J., W. S. Kim, T.-J. Jeong, B.-H. Chung, K. P. Park, S.-Y. Suh, D.-G. Huh, Y.-J. Lee, S.-H. Jang, D.-G. Yoo, J.-H. Kim, G.-S. Kong, H.-T. Kim, N.-H. Koo, S.-P. Kim, K.-O. Kim, I.-K. Kwon, J.-H. Lee, M. H. Kang, J.-H. Oh, D. Sunwoo, H.-C. Han, H. Y. Lee, Y.I. Kwon, B.-K. Son, S.-J. Kim, J.-K. Kim, H.-J. Kim, Y.-G. Kim, G.-S. Seo, J.-K. Choi, K.-D. Hwang, M.-H. Park, I.-S. Kim, Y.-S. Baek, Y .-C. Lee, J.-H. Lee, B.H. Jo, H. Lee, and W.-M. Sung, 2004: Study on Techniques for Gas Hydrate Exploration and Development, KIGAM Research Report, KR-04(cd)-09, 525 pp. (in Korean)

Ryu, B. J., M. Riedel, J. H. Kim, R. D. Hyndman, Y. J. Lee, B. H. Chung, and I. S. Kim, 2009: Gas hydrates in the western deep-water Ulleung Basin, East Sea of Korea. 
Mar.Petrol.Geol., 26, 1483-1498, doi: 10.1016/j.marpetgeo.2009.02.004. [Link]

Ryu, B. J., G.-Y. Kim, J.-H. Chun, J.-J. Bahk, J. Y. Lee, J.-H. Kim, D.-G. Yoo, T. S. Collett, M. Riedel, M. E. Torres, S.-R. Lee, and the UBGH2 scientists, 2012: The Second Ulleung Basin Gas Hydrate Drilling Expedition 2 (UBGH2) Expedition Report, KIGAM, Daejeon, $667 \mathrm{pp}$.

Ryu, B. J., T. S. Collett, M. Riedel, G. Y. Kim, J.-H. Chun, J.-J. Bahk, J. Y. Lee, J.-H. Kim, and D.-G. Yoo, 2013: Scientific Results of the Second Gas Hydrate Drilling Expedition in the Ulleung Basin (UBGH2). Mar. Petrol. Geol., 47, 1-20, doi: 10.1016/j.marpetgeo.2013.07.007. [Link]

Ryu, B. J., D.-G. Yoo, N.-K. Kang, B. Y. Yi, G. Y. Kim, J. J. Bahk, and J. Y. Lee, 2014: In-place Gas Hydrate Resources in the Ulleung Basin, East Sea of Korea. Fire in the Ice, NETL Methane Hydrate Newsletter, Vol. 14, 9-10.

Shipley, T. H., M. H. Houston, R. T. Buffler, F. J. Shaub, K. J. McMillen, J. W. Ladd, and J. L. Worzel, 1979: Seismic Evidence for widespread possible gas hydrate horizons on continental slopes and rises. AAPG Bull., 63, 2204-2213, doi: 10.1306/2f91890a-16ce-11d78645000102c1865d. [Link]

Sloan, E. D., 1998: Clathrate Hydrates of Natural Gases, Second Edition, Revised and Expanded, CRC Press, New York, 705 pp.

Spence, G. D., R. R. Haacke, and R. D. Hyndman, 2010: 4. Seismic indicators of natural gas hydrate and underlying free gas. In: Riedel, M., E. C. Willoughby, and S. Chopra (Eds.), Geophysical Characterization of Gas Hydrates, Society of Exploration Geophysicists, 3971, doi: 10.1190/1.9781560802197.ch4. [Link]

Stein, R., 1991: Accumulation of Organic Carbon in Marine Sediments: Results from the Deep Sea Drilling Project/Ocean Drilling Program (DSDP/ODP), Springer, Berlin, Heidelberg, 217 pp, doi: 10.1007/bfb0010382. [Link]

Su, X., C.-B. Song, and N.-Q. Fang, 2006: Relationship between sediment granulometry and the presence of gas hydrate on Hydrate Ridge. In: Tréhu, A. M., G. Bohrmann, M. E. Torres, and F. S. Colwell (Eds.), Proceedings of the Ocean Drilling Program, Scientific Results, Vol. 204, College Station, TX (Ocean Drilling Program), 1-30, doi: 10.2973/odp.proc. sr.204.115.2006. [Link]

Tak, H., J. Byun, S. J. Seol, and D. G. Yoo, 2013: Zerooffset vertical seismic profiling survey and estimation of gas hydrate concentration from borehole data from the Ulleung Basin, Korea. Mar. Petrol. Geol., 47, 204213, doi: 10.1016/j.marpetgeo.2013.06.011. [Link]

Tamaki, K., K. Suyehiro, J. Allan, J. C. J. Ingle, and K. A.
Pisciotto, 1992: Tectonic synthesis and implications of Japan Sea ODP drilling. In: Tamaki, K., K. Suyehiro, J. Allen, and M. McWilliams (Eds.), Proceedings of the Ocean Drilling Program, Scientific Results, Vol. 127/128 (Pt. 2), College Station, TX (Ocean Drilling Program), 1333-1348, doi: 10.2973/odp.proc. sr.127128-2.240.1992. [Link]

Tissot, B. P. and D. H. Welte, 1984: Petroleum Formation and Occurrence, Springer, Berlin, Heidelberg, 538 pp, doi: 10.1007/978-3-642-87813-8. [Link]

Tomaru, H., R. Matsumoto, M.E. Torres, and W. S. Borowski, 2006: Geological and geochemical constraints on the isotopic composition of interstitial waters from the Hydrate Ridge region, Cascadia Continental Margin. In: Tréhu, A. M., G. Bohrmann, M. E. Torres, and F. S. Colwell (Eds.), Proceedings of the Ocean Drilling Program, Scientific Results, Vol. 204, College Station, TX (Ocean Drilling Program), 1-20, doi: 10.2973/odp. proc.sr.204.109.2006. [Link]

Tréhu, A. M., P. E. Long, M. E. Torres, G. Bohrmann, F. R. Rack, T. S. Collett, D. S. Goldberg, A. V. Milkov, M. Riedel, P. Schultheiss, N. L. Bangs, S. R. Barr, W. S. Borowski, G. E. Claypool, M. E. Delwiche, G. R. Dickens, E. Gracia, G. Guerin, M. Holland, J. E. Johnson, Y.-J. Lee, C.-S. Liu, X. Su, B. Teichert, H. Tomaru, M. Vanneste, M. Watanabe, and J. L. Weinberger, 2004: Three-dimensional distribution of gas hydrate beneath southern Hydrate Ridge: Constraints from ODP Leg 204. Earth Planet. Sci. Lett., 222, 845862, doi: 10.1016/j.epsl.2004.03.035. [Link]

Warner, M., 1990: Absolute reflection coefficients from deep Seismic reflections. Tectonophysics, 173, 15-23, doi: 10.1016/0040-1951(90)90199-i. [Link]

Westbrook, G. K., B. Carson, R. J. Musgrave, J. Ashi, B. Baranov, K. M. Brown, A. Camerlenghi, J.-P. Caulet, N. Chamov, M. B. Clennell, B. A. Cragg, P. Dietrich, J.-P. Foucher, B. Housen, M. Hovland, R. D. Jarrard, M. Kastner, A. Kopf, M. E. MacKay, C. Moore, K. Moran, R. J. Parkes, J. Sample, T. Sato, E. J. Screaton, H. J. Tobin, M. J. Whiticar, and S. D. Zellers, 1994: Proceedings of the Ocean Drilling Program, Initial Reports, Vol. 146 (Pt. 1), College Station, TX (Ocean Drilling Program), 611 pp, doi: 10.2973/odp.proc. ir.146-1.1994. [Link]

Yi, B. Y., G. H. Lee, S. Horozal, D. G. Yoo, B. J. Ryu, N. K. Kang, S. R. Lee, and H. J. Kim, 2011: Qualitative assessment of gas hydrate and gas concentrations from the AVO characteristics of the BSR in the Ulleung Basin, East Sea (Japan Sea). Mar. Petrol. Geol., 28, 19531966, doi: 10.1016/j.marpetgeo.2010.12.001. [Link]

Yoo, D. G., D. H. Kang, N. H. Koo, W. S. Kim, G. Y. Kim, B. Y. Kim, S. H. Chung, Y. J. Kim, H. Y. Lee, K. P. Park, G. H. Lee, and S. C. Park, 2008: Geophysical 
evidence for the occurrence of gas hydrate in the Ulleung Basin, East Sea. J. Geol. Soc. Korea, 44, 645-655. (in Korean)

Yoo, D. G., N. K. Kang, B. Y. Yi, G. Y. Kim, B. J. Ryu, K. Lee, G. H. Lee, and M. Riedel, 2013: Occurrence and seismic characteristics of gas hydrate in the Ulleung Basin, East Sea. Mar. Petrol. Geol., 47, 236-247, doi: 10.1016/j.marpetgeo.2013.07.001. [Link]

Yoon, S. H. and S. K. Chough, 1995: Regional strike slip in the eastern continental margin of Korea and its tectonic implications for the evolution of Ulleung Basin, East Sea (Sea of Japan). Geol. Soc. Am. Bull., 107, 83, doi: 10.1130/0016-7606(1995)107<0083:RSSITE >2.3.CO ;2. [Link]

Yuan, T., G. D. Spence, R. D. Hyndman, T. A. Minshull, and S. C. Singh, 1999: Seismic velocity studies of a gas hydrate bottom-simulating reflector on the northern Cascadia continental margin: Amplitude modeling and full waveform inversion. J. Geophys. Res., 104, 1179-1191, doi: 10.1029/1998JB900020. [Link] 